\title{
Explaining the Global Pattern of Current Account Imbalances
}

\author{
Joseph W. Gruber and Steven B. Kamin*
}

June 2006

\begin{abstract}
This paper assesses some of the explanations that have been put forward for the global pattern of current account imbalances that has emerged in recent years: in particular, the large U.S. current account deficit and the large surpluses of the Asian developing economies. Based on the approach developed by Chinn and Prasad (2003), we use data for 61 countries during 1982-2003 to estimate panel regression models for the ratio of the current account balance to GDP. We find that a model that includes as its explanatory variables the standard determinants of current accounts proposed in the literature-per capita income, relative growth rates, the fiscal balance, demographic variables, and economic openness-can account for neither the large U.S. deficit nor large Asian surpluses of the 1997-2003 period. However, when we include a variable representing financial crises, which might be expected to restrain domestic demand and boost the current account balance, the model explains much of developing Asia's swing into surplus since 1997. Even so, the model cannot explain why the capital outflows associated with Asia's current account surpluses were channeled primarily into the U.S. economy. Observers have pointed to strong growth performance and a favorable institutional environment as elements attracting foreign investment into the United States, and we found strong evidence that good performance in these areas significantly reduces the current account balance. While a model incorporating these factors still fails to predict the large U.S. current account deficit (and, in fact, predicts a slight surplus), it does predict a U.S. current account balance that is relatively weaker than the aggregate balance of developing Asia.
\end{abstract}

Keywords: current account, financial crisis, capital flows

JEL Codes: F21, F32

*The authors are Economist and Associate Director, respectively, in the International Finance Division of the Federal Reserve Board. The views expressed in this paper are solely the responsibility of the authors and should not be interpreted as reflecting the views of the Board of Governors of the Federal Reserve System or of any person associated with the Federal Reserve System. We would like to thank Joseph Gagnon, Jane Ihrig, John Rogers, and seminar participants in the International Finance Workshop and at the IMF for helpful comments and advice. Benjamin Vallis provided able research assistance. Correspondence should be addressed to: Joseph W. Gruber

(joseph.w.gruber@frb.gov) or Steven B.Kamin(steven.kamin@frb.gov), Board of Governors of the Federal Reserve System, Washington DC 20551, USA. 


\section{Introduction}

The pattern of global current account imbalances has received considerable attention in recent years. Most prominently, the U.S. current account deficit has widened from \$125 billion in 1995 to \$668 billion in 2004 (shown in Figure 1), or from 1.5 percent of GDP to 5.7 percent of GDP. This deficit is mirrored in some equally marked surpluses on the part of some of the United States' trading partners. The current account balances of major developing East Asian economies (China, Hong Kong, Indonesia, Korea, Malaysia, Philippines, Singapore, Taiwan, and Thailand) have moved from an aggregate deficit of \$27 billion in 1995 to a surplus of \$186 billion in 2004, or from negative 1.2 percent of GDP to positive 5.3 percent of GDP. More generally, the aggregate current account balance of the developing countries moved into surplus starting in 2000.

The present pattern of external imbalances appears inconsistent with the standard view that mature industrial economies should be exporting capital to poor developing countries. Because developing countries have higher labor/capital ratios, they should in principle have higher marginal productivities of capital and thus attract capital from labor-poor industrial economies. Moreover, if developing countries can expect faster income growth as they catch up to industrial countries, this provides an incentive for them to borrow against their higher future income, also leading to current account deficits.

There is no consensus explanation for the current pattern of international capital flows, and many hypotheses have been put forward: U.S. fiscal deficits; declines in U.S. private saving; the surge in U.S. productivity growth; increases in global financial intermediation; a global savings glut; a rash of emerging market financial crises; and exchange rate pegs by our trading partners. However, many of these factors are quite amorphous, and it has been difficult to muster support for one explanation against another. 
By the same token, it has been even more difficult to assess all of the proposed factors jointly and compare their separate contributions to the international pattern of current account imbalances. Ferguson (2005) reports one of the few attempts to conduct such as exercise. The Federal Reserve staff's open economy macroeconomic simulation model is used to gauge the contribution of different shocks to the evolution of the U.S. trade deficit. The widening of the deficit is attributed primarily to the rise in U.S. productivity growth, a fall in the risk premium on dollar assets, and the weakening of foreign domestic demand; other factors, including the U.S. fiscal deficit and decline in private saving, receive less weight in the decomposition analysis. This exercise is undeniably useful in enhancing our understanding of the roots of the U.S. trade deficit. Nevertheless, the simulation model is unlikely to precisely capture the economic linkages involved in the determination of the external balance, and identifying the quantitative magnitude of the shocks affecting the trade deficit is both difficult and subjective.

In this paper, we adopt a more empirical but less structured approach to explaining the recent emergence of large current account imbalances. Our approach jumps off from the influential research of Chinn and Prasad (2003). ${ }^{1}$ Chinn and Prasad developed a large multi-country database for the period 1971-1995 and estimated a battery of cross-sectional and panel regressions relating current account/GDP ratios to a wide range of potential determinants, including, among others, the fiscal deficit, net foreign asset position, per capita income, output growth, demographic variables, terms of trade volatility, and openness to trade. Based on a similar approach, but with altered specifications and data extending through 2003, we estimate panel regression models to explain the current account/GDP ratios of 61 countries. We use these models to assess preliminary hypotheses

\footnotetext{
${ }^{1}$ This research has been updated in Chinn and Ito (2005), in work conducted at the same time; but independently of ours.
} 
regarding the determinants of current account balances, and we also assess the extent to which our models can explain the international pattern of current account balances that has emerged in recent years, particularly the U.S. deficit and developing Asian surpluses. ${ }^{2}$

To summarize our key results, we find that a regression model comprised of the standard determinants of the current account identified in the literature-per capita income, output growth, fiscal balances, net foreign assets, economic openness, and demographic variables-can explain neither the large U.S. current account deficit of recent years nor the large developing Asian surpluses. This tends to confirm suspicions that whatever is causing these outsized external imbalances, it is something not readily explained by conventional theory.

However, a variant of our standard model that is augmented by a variable representing the incidence of financial crisis does do a good job of explaining the emergence of developing Asia's current account surpluses. Financial crises persistently restrain both the supply and demand for credit, depressing domestic demand and boosting external balances. The financial crises in developing Asia in the late 1990s apparently played a key role in promoting surpluses, both directly by restraining domestic spending, particularly investment, and, perhaps, indirectly by encouraging the authorities to take measures to keep their exchange rates competitive.

Even though our augmented model can explain why the Asian economies moved into surplus, it does not explain why the U.S. economy moved so deep into deficit. (In fact, the model predicts a small surplus for the United States in the recent period.) Put another way, the financial crisis that swept developing Asia in the late 1990s apparently contributed to the subsequent substantial capital outflows from that region, and thus to what Bernanke (2005) has referred to as a

\footnotetext{
${ }^{2}$ Our model imposes no long-run solvency condition. As such, there is no guarantee that the model is consistent with a long-run equilibrium. Thus, we are implicitly assuming that long-run solvency concerns play no role in the determination of current account balances.
} 
"global savings glut". However, it remains unclear why those surplus savings ended up in the United States rather than being spread more evenly throughout the world.

Analysts have posited several factors that could account for investors' special attraction to U.S. assets in recent years, including the United States' strong growth, reliable investor protections, and market-friendly regulations. We find that in many specifications of our model, a variable representing the change in output growth significantly lowers the current account balance. Additionally, favorable scores on measures of the quality of government institutions are associated with statistically significant reductions in current account balances. Even so, our model fails to predict the substantial U.S. current account deficits of recent years, and still predicts a small surplus.

While the model does poorly at predicting the actual magnitude of the U.S. current account deficit it does correctly predict a weaker balance in recent years for the United States than for the developing Asian economies in aggregate. Better institutions in the United States, in combination with slowing growth and the financial crisis in Asia, lead the model to predict relatively higher current account balances in Asia than in the United States, even taking into account the United States’ much higher level of economic development.

The plan of this paper is as follows. Section II reviews different explanations that have been put forward for the emergence of large external imbalances in recent years. Section III describes the methodology and data used to develop panel regression models of the current account/GDP ratio. The estimation results and the ability of the basic model to predict current account balances are addressed in Section IV, while Section V focuses on the role of government institutions in the determination of the current account. Section VI addresses the robustness of our estimates to alternative specifications, while section VII concludes. 


\section{Explanations for the Pattern of Large External Imbalances}

The proximate causes of the widening of the U.S. current account deficit and corresponding widening of our trading partners' deficits are reasonably obvious: the rise in the dollar between 1995 and early 2002 (which has given up only part of its gains since then); the pickup in U.S. real GDP growth relative to that of its trading partners; and the higher elasticity of U.S. imports with

respect to income than U.S. exports with respect to foreign income (the Houthakker-Magee effect). ${ }^{3}$ Yet, listing these proximate factors leaves open the more fundamental causes of the deficit. What caused the appreciation of the dollar? Why has U.S. growth translated into so much more imports than has foreign growth? This section reviews some of the answers to these deeper questions.

1. Expansion of the fiscal deficit The simultaneous emergence of fiscal and current account deficits in the United States in the mid-1990s gave rise to the "twin deficits" hypothesis. (See, among others, Truman, 2004, and Gramlich, 2004.) At its simplest, this hypothesis notes that the current account balance is equal to saving minus investment, so any expansion of the fiscal deficit that lowers public saving must lower the current account balance. In the more sophisticated version of the hypothesis, which takes into account the endogeneity of private saving and investment decisions, fiscal expansion boosts domestic spending, pushing up domestic interest rates relative to foreign rates; this attracts foreign investors and buoys the dollar, thereby widening the current account deficit. Some observers see the U.S. budget deficit as an important factor in the economy’s external imbalance. (Cline, 2005, Chinn, 2005, Chinn and Ito, 2005) However, analysis using simulation models suggests that the budget deficit may not have played a central role (Erceg, Guerrieri, and Gust, 2005a, Ferguson, 2005).

${ }^{3}$ See, among others, Chinn (2004), Mann (1999, 2002, and 2004), and Roubini and Setzer (2004). 
2. Declines in private saving rates Since the mid-1990s, the U.S. personal saving rate has moved down from about 5 percent of disposable income to below 2 percent, while the gross private saving rate, which also incorporates corporate saving, has also declined a bit. Along with the slide in public saving rates, the decline in private saving could help to explain the widening of the current account deficit. However, it is not clear whether the decline in saving is autonomous, perhaps reflecting financial innovations that have made it easier for Americans to borrow, or the endogenous response to other developments; for example, Bernanke (2005) argues that an excess of saving abroad has simultaneously boosted the U.S. current account deficit and depressed U.S. private saving. Additionally, even an autonomous decline in saving might have little impact on the current account balance. In the model simulation described in Ferguson (2005), a decline in private saving, by boosting interest rates, crowds out investment more than it crowds in net exports.

3. U.S. productivity surge The growth rate of U.S. labor productivity rose from some $1 \frac{1 / 2}{2}$ percent annually in the 1975-95 period to about 3 percent subsequently. This increase likely boosted perceived rates of return on U.S. assets, generating capital inflows and buoying the dollar. Expectations of higher rates of return likely also motivated greater domestic investment, and consumption may have been supported by increases in stock prices and perceived long-run income. As shown in simulation experiments described in Erceg, Gust, and Guerrieri (2005b) and Ferguson (2005), all these developments may have contributed to larger trade deficits.

4. Expanding global financial intermediation In recent years, the correlation between national saving and investment rates-the so-called Feldstein-Horioka paradox-has declined, suggesting that savings are being used to finance investment to a greater extent than in the past (Blanchard and Giavazzi, 2002, and Gruber, 2004). Additionally, there is considerable evidence that the extent of home bias in portfolio allocation-that is, the tendency for portfolios to be 
overweight domestic assets-is declining (Ahearne et. al., 2004). Greenspan (2003) has suggested that these trends signal improvements in international financial intermediation which allow larger external imbalances to be financed than in the past, an observation that is consistent with recent increases in the absolute value of global current account deficits, shown in Figure 2. Analyses by Blanchard, Giavazzi, and Sa (2005) and Edwards (2005) also accord a role to reduced home bias in the widening of U.S. deficits.

However, the increased ability of the international financial system to move capital across borders does not, by itself, mean that it is the United States that would be expected to exploit that improved ability. Observers point to various strengths of the U.S. economy-its favorable investment climate, protections of investor rights, and solid rates of return-as making it likely that the United States would attract international capital once it became available.

5. Global savings glut/emerging market financial crises Bernanke (2005) argues that the large U.S. current account deficit owes importantly to a surge in the availability of saving from overseas. He notes that much of the increased flow of foreign saving has come from developing countries, a development he attributes in large part to the series of financial crises experienced in the past decade. Emerging market financial crises may generate current account surpluses (or lower deficits) through several channels: the economy may lose access to foreign credit; financial intermediation within the economy may become obstructed, causing a credit crunch; balance sheet problems among firms and consumers may restrain domestic spending; and authorities may respond to the weakness in domestic demand by taking actions to keep the exchange rate competitive so as to maintain external demand. As discussed in Kamin (2005) and shown in Figures 3a through 3d, all of those factors, to greater and lesser degrees, were involved in the Asian developing countries' swing into surplus: investment rates collapsed, along with bank lending, while exchange rates 
remained weak against the dollar, even as the currencies of foreign industrial economies were appreciating.

Of course, as in the increased global financial intermediation story, the increased flows of capital from developing countries cannot, by themselves, explain the rise in the U.S. current account deficit-in principle, other industrial economies might also have increased their net imports of capital. Again, to explain the rise in U.S. deficits, one must suggest why investors found the United States to be a particularly attractive target for their funds.

6. Developing Asian exchange rate intervention Whether described as the "revived Bretton Woods system” (Dooley, Folkerts-Landau, and Garber, 2003 and 2004) or “codependency” (Mann, 2004), one explanation put forward for the large U.S. current account deficits is, simply, that some of our trading partners (mainly Asian) have been intervening to keep their currencies competitive and promote their own growth. In principle, this explanation does not differ greatly from the savings glut/financial crisis story in \#5, above. Mann, for example, cites the late 1990s financial crises as a key factor in the exchange rate policies of the developing Asian economies, suggesting that at some future point those policies may change. Dooley, FolkertsLandau, and Garber, however, argue that intervention to keep exchange rates competitive and produce current account surpluses is in the interest of all developing countries, with the implication that such surpluses may be with us for some time to come. They do not explain why the developing countries apparently waited until 1999 to adopt such a strategy.

7. Rising oil prices This factor is not, in some sense, as "fundamental" as the other explanations for the large U.S. deficit reviewed above. Nonetheless, between 1996 and 2004, U.S. imports of oil rose by nearly $\$ 110$ billion. Much of this rise owed to higher prices, and thus 
accounts for about 1 percentage point of the 4.1 percentage point rise in the current account/GDP ratio from 1996 to 2004.

\section{Empirical Methodology and Data}

Our empirical research will not be able to shed light on all of the potential explanations for the large U.S. current account deficit surveyed above. It should, however, bear on at least some of those stories.

Our sample consists of observations on 61 countries over the period between 1982 and 2003. Since our primary interest is the medium and long term determinants of current account balances, we consider multi-year averages of annual observations as in Chinn and Prasad (2003). ${ }^{4}$ Averages were constructed over 1982 - 1986, 1987 - 1991, 1992 - 1996, and 1997 - 2003, giving us four period observations for each of our 61 cross-sections. For some series a lagged observation was created based on the 1977 - 1981 average. In cases of missing annual observations, averages were calculated based on the remaining years in a period, allowing a larger sample of developing countries than would have otherwise been possible.

Our primary method of analysis consists of panel regressions with the ratio of the current account balance to GDP as the dependent variable. For all of the regressions we include a period fixed effect, thereby allowing the average current account balance across the cross-section to vary from period to period. We do not include country fixed effects, since allowing country-specific means would prevent us from analyzing cross-country differences in current accounts.

\footnotetext{
${ }^{4}$ The consideration of multi-year averages allows us to abstract somewhat from current account dynamics driven by the business cycle. By focusing on the medium-term we are able to better identify current account dynamics associated with changes in fundamental determinants rather than dynamics that might result from various frictions and related adjustment processes.
} 
To calculate the current account to GDP ratio, we use the current account measured in U.S. dollars and GDP converted to dollars at the annual average market exchange rate. Using ratios controls for nominal changes in current accounts and GDP.

We briefly review the explanatory variables in our models below. In that the current account is inherently a relative measure, most of the independent variables were calculated as ratios to sample averages.

Per capita income As noted above, economic theory predicts that labor-intensive capitalpoor developing countries should be net importers of capital, and hence run current account deficits, while capital-rich developed countries should export capital and run current surpluses. To capture this dynamic, we include the ratio of real per capita income to its sample mean in our regressions. Changes in growth rates An increase in the growth rate of productivity relative to other countries should be associated with a larger current account balance, as an increase in the return on capital increases investment and the potential for higher future income decreases saving. In our model, changes in productivity growth are proxied by the change in the growth rate of real per capita income; this measure is available for many countries, although it does not control for changes in labor force participation or hours worked. The growth rates were constructed as the multi-year average of the difference of annual growth from the GDP-weighted sample mean. In some regressions, we control for changes in labor force participation by using per employee GDP rather than per capita GDP.

Fiscal balance The fiscal balance was calculated as a ratio to GDP and expressed as the difference from the mean GDP-weighted ratio for the sample.

Net foreign assets A country's net foreign asset (NFA) position directly affects its net investment income, and therefore its current account balance. Because the NFA position is, in 
effect, the accumulation of past current account balances, the lagged value of the position, expressed as a ratio to GDP, is entered into the regressions to avoid correlation with the independent variable. The lack of NFA data for a number of countries, including Hong Kong, led us to substitute the lagged current account in some regressions; these measures are highly correlated. Additionally, as shown in Gruber (2004), the inclusion of the lagged current account can be theoretically justified if consumers exhibit habit formation.

Demographics The life-cycle theory of consumption and saving predicts that young households borrow, middle-age households save for retirement, and households in retirement dissave. Therefore relatively young and relatively old countries are both more likely to run current account deficits. To capture these effects we included both the youth dependency ratio and the oldage dependency ratio in the regressions. The youth dependency ratio was defined as the ratio of the population ages 0 - 14 to the working age population (ages 15 - 64), while the old-age dependency ratio was defined as the ratio of the population 65 and older to the working age population. Both measures were entered as deviations from a GDP-weighted sample mean.

Openness Openness was identified by Chinn and Prasad (2003) as a potential determinant of the current account. We define openness as the sum of imports and exports relative to GDP.

Oil Balance In order to capture the effect on current accounts of terms-of-trade shocks related to oil prices, we included the nominal oil balance to GDP ratio in the regressions. Although the oil balance is a component of the overall current account balance, changes in the oil balance do not have a one-for-one impact on the current account balance if the non-oil balance also responds to oil price shocks. As shown in figure 10, the relationship between the two balances is surprisingly indistinct. It is important to note that our sample ends in 2003, and thus misses much of the recent upward swing in oil prices. 
Financial crises Our financial crisis variable is based on a list of banking crises developed by Caprio and Klingebiel (2003), who identify a banking crisis by the extent to which bank capital in a country is exhausted. Crises are categorized as systemic or non-systemic, depending on how widespread capital losses are. We consider only crises flagged by Caprio and Klingebiel as being systemic. ${ }^{5}$ As the first step in constructing our financial crises variable, we construct a dummy variable that takes on the value of one if a country is in crisis and zero otherwise.

As with many other of the explanatory variables we consider, a financial crisis should affect a particular country's current account only in relative terms. If all countries in the sample were simultaneously in crisis, one would not expect there to be an impact on any one country's current account balance. Accordingly, the financial crisis variable we use in our model is a relative measure; it is constructed by subtracting from the value of each country's annual zero-one financial crisis dummy a GDP-weighted average of these dummies, aggregated across all the countries in our sample. The GDP-weighted annual averages thus represent the percentage of the aggregate sample GDP in crisis in each year, represented in Figure 4. The aggregate series moves up in the early 1980s with the Latin American debt crisis, and then jumps in 1991 with the onset of the Japanese banking crisis. The aggregate index is relatively flat through the 1990s as several Nordic and Latin American crises fade around the time that the Asian financial crisis begins.

In addition to the financial crisis variable, we also include as an explanatory variable in our model an interaction term, the financial crisis variable multiplied by the openness variable. The

\footnotetext{
${ }^{5}$ Our one deviation from the Caprio and Klingebiel list is that their list identified China having a banking crisis in the "1990s", but given that the country's banking problems have not been resolved, we extend that crisis through the present.
} 
rationale for this is that more open economies are likely to have larger tradable goods sectors and thus be able to adjust their external balances more flexibly in response to financial crisis. ${ }^{6}$

Finally, it is worth emphasizing that the financial crises in the Caprio and Klingbiel dataset are measures of banking crises, not currency crises such as those identified by Frankel and Rose (1996) or Kaminsky, Lizondo, and Reinhart (1998), although there may be considerable overlaps among the two concepts. It would be inappropriate to use currency crises per se in our model. Such measures often signal a sharp exchange rate depreciation, thus representing a proximate determinant of the current account rather than a more fundamental factor. Moreover, currency crises often reflect sharp reversals of capital flows, but such reversals are the capital-account counterparts to swings of the current account, not an independent cause of them.

Quality of government institutions As noted above, one explanation for the attractiveness of the United States to foreign investors is the quality of U.S. institutions, which both protects investor rights and enhances rates of return. In order to capture the importance of institutions to capital flows, we include a set of governance indicators described in Kaufmann, Kraay, and Mastruzzi (2005), in a subset of our regressions. ${ }^{7}$ The Kaufmann, Kraay, and Mastruzzi data set consists of six indicators (Voice and Accountability, Political Stability, Government Effectiveness, Regulatory Quality, Rule of Law, and Control of Corruption) with four annual observations (1996, 1998, 2000,

${ }^{6}$ For example, consider two economies, both with trade deficits of 5 percent of GDP, and both of whom experience declines in imports and increases in exports of 10 percent following a financial crisis. In a very open economy-say, with imports of 60 percent of GDP and exports of 55 percentimports would fall to 54 percent of GDP and exports would rise to 60.5 percent of GDP, causing the trade balance to swing to a surplus of 6.5 percent of GDP. Conversely, in a more closed economysay, with imports of 20 percent of GDP and exports of 15 percent-the trade deficit would narrow but not close entirely.

7 Introducing institutional measures into a cross-country model of current accounts is novel; the only other research we are aware of that does this is Chinn and Ito (2005). They use different measures of institutional quality, drawn from the International Country Risk Guide (ICRG). 
and 2002) for each indicator. The indicators, estimated using an unobserved components model with data from a wide array of sources, range from -2.5 to 2.5 , with a higher value representing higher-quality institutions.

For each country we matched the average of the 1996 and 1998 indicators to the 1992 - 1996 period of the panel and the average of the 2000 and 2002 values to our 1997 - 2003 period of the panel. We examine both a composite average of the indicators as well as the individual indicators.

\section{Basic Estimation Results}

Table 1 presents the estimation results for several variants of our model. As described above, the model is estimated over data organized into period-averages for four different periods: 1982-1986, 1987-1991, 1992-1996, and 1997-2003. Both a constant and separate time dummies for each period are included in the model but not shown. For each explanatory variable, the first row represents the coefficient estimate and the second row represents the t-statistic; coefficients that are statistically different from zero at the 90 percent level or higher are indicated in bold. In the regressions shown in Table 1, we have excluded Singapore from the sample, as it is an extreme outlier in terms of current account history (an average surplus of roughly 20 percent of GDP in the 1997 - 2003 period) and net foreign assets (reaching 155 percent of GDP in 2003), and it also is unusually influential in some specifications of our model; the robustness of our results to this exclusion is discussed below and indicated in Tables $5 \mathrm{a}$ and $5 \mathrm{~b}$.

Column 1 indicates the results from the simplest model, which contains standard variables posited by the literature as helping to determine the current account balance. All of the coefficients have the expected sign, and most of them are significantly different from zero or nearly so. Larger current account balances (where positive indicates a surplus) are associated with higher per capita incomes, lower changes in growth, higher fiscal balances, higher net foreign asset positions, lower 
shares of youth and elderly in the population, greater degrees of economic openness, and a positive nominal oil balance.

The coefficient on the fiscal balance variable is quite low, at .11; however, our estimate is not all that far from many of the coefficients estimated by Chinn and Prasad (2003), Chinn and Ito (2005) or Bussiere, Fratzscher, and Muller (2004, 2005), which range from less than 0.1 to a little over 0.4.

The coefficient on output growth also is low and insignificant, but this is consistent with Chinn and Prasad (2003) and Chinn and Ito (2005), who use a slightly different specification. Bussiere, Fratzcher, and Muller (2005) find a larger and significant negative impact on the current account, but using productivity growth rather than output growth and using data only for industrial economies. (See, also, Glick and Rogoff, 1995.) As shown in the first column of Table 6, using a more specific measure of productivity--output per employee rather than output per capita-for the entire sample of industrial and developing countries for which data are available does not improve these results; as using the productivity measure requires shrinking the number of observations, we stick with the output measure for use in our model.

The coefficient on the nominal oil balance is positive as expected, but the value is far smaller than one, such that the oil balance does not appear to have a direct impact on the current account balance. The low value of the coefficient is consistent with the scatterplot of current accounts and trade balances shown in Figure 10. Clearly across countries, changes in the nominal oil balance are over time largely offset by changes in the non-oil balance, such the current account balance remains relatively unaffected.

How well does the model shown in column 1 capture the recent international pattern of current account imbalances? Figure 5 plots, for the 1997-2003 period, the model's predictions of 
the current account/GDP ratios for selected countries on the X-axis against their actual values on the Y-axis. Countries whose current account balances were predicted exactly will fall on the 45 degree line; the other two lines represent +/- twice the standard error of regression, and thus approximate a 95 percent confidence interval. The figure makes clear that the simplest model under-predicts both the U.S. current account deficit -- in fact, it predicts a slight surplus -- and most of the developing Asian current account surpluses, with the size of the miss being statistically significant for several of the countries.

To provide a more precise assessment of the extent to which the model mispredicts the U.S. and developing Asian balances, column 2 presents the same model, but with separate dummy variables for each of those countries during the 1997-2003 period. These separate dummies have the effect of essentially excluding these observations from the regression, while the coefficients on these dummies represent the difference between their actual current account balances and the model's prediction. These coefficients confirm what is already evident in Figure 5, that for China, Indonesia, Malaysia, the Philippines, and Thailand, current account surpluses during 1997-2003 were significantly above the model prediction. For the United States, the current account deficit was significantly above the model prediction, with the miss being nearly 4 percentage points of GDP.

Column 3 represents the same basic model as in column 1, but with the addition of the financial crisis and (financial crisis)*(openness) variables described in Section III. The coefficients on both variables are statistically significant, but have opposite signs. Their values imply that for countries with an openness ratio of .3 or higher, a financial crisis raises the current account balance; in our sample, 37 of the 40 developing countries had openness ratios exceeding this level, including all of the Asian countries. Compared with the model shown in column 1, the addition of the 
financial crisis variables raises the adjusted $\mathrm{R}^{2}$ from .29 to .35 and reduces the standard error of the regression slightly as well. More importantly, as indicated in Figure 6, the addition of the financial crisis variables substantially increases the model's predictions of the developing Asian current account balances, so that these now fall within the 95 percent confidence interval for the model. This represents significant evidence that the region's outsized surpluses in the 1997-2003 years importantly reflected the on-going effects of the financial crisis that started at the onset of that period. The predicted current accounts for non-crisis countries are largely unaffected by the addition of the crisis variable to the model.

The evidence shown in column 3, by itself, leaves open the possibility that the significant coefficients on the financial crisis variables are being driven exclusively by the behavior of the developing Asian nations in the 1997-2003 period. It is possible that, absent those observations, financial crises would not have been estimated to have pronounced effects on the current account balance and the large Asian surpluses would remain unexplained. Column 4 presents the estimation results when, as in column 2, we add separate dummy variables for each of the developing Asian economies (as well as the United States) in the 1997-2003 period, thus effectively removing them from the estimation sample. The resultant coefficients on the financial crisis variable are remarkably similar to those in column 3 . The coefficient on the (financial crisis)*(openness) variable declines in significance, as would be expected as the removal of a large number of observations combining both financial crises and large current account surpluses, but remains significantly different from zero at the 95 percent level.

Thus, the regression supports our portrayal of financial crises as a general factor boosting current account balances, not something specific to the developing Asian countries in recent years. Moreover, as indicated by the coefficients on the Asian dummy variables, even when the Asian 
observations in the 1997-2003 period effectively are excluded from the sample, the model continues to predict their substantial surpluses with much greater accuracy than the model without financial crises.

Importantly, while the models in columns 3 and 4 explain much of the Asian current account surpluses in recent years, they offer no improved ability to predict the U.S. deficit; as with the models that do not include the financial crises variables, they continue to predict U.S. balances that are about $4 \frac{1}{2}$ percentage points of GDP too high. This is confirmed in column 5 , where only a dummy variable for the United States in the 1997-2003 period is included, and it shows an overprediction of over 5 percentage points of GDP.

\section{Institutional Quality and the U.S. Current Account Balance}

To improve the model's ability to capture the factors underlying foreign investors' strong attraction to the United States in recent years, we added to the model the composite indicator of the quality of government institutions outlined in Kaufmann, Kraay, and Mastruzzi (2005). As described in Section III, above, this measure is an average of six separate sub-indexes: voice; political stability; government effectiveness; regulatory burden; rule of law; and corruption. This measure is only available biennially for 1996 onwards, and thus requires restricting estimation of the model to the last two panels: 1991-95 and 1997-2003.

In order to provide a baseline against which to compare results, columns 1 and 2 of Table 2 replicate the model shown in columns 3 and 5 of Table 1, but estimated only over the 1992-96 and 1997-2003 periods; this model includes the financial crisis variables but not the government institutions index, and is estimated both without and with a dummy variable for the United States in the 1997-2003 period. By and large, the coefficients in the models estimated over all four periods (Table 1) and estimated only over the last two periods (Table 2) are similar. The most important 
difference is that the coefficient on output growth becomes substantially larger and negative, and significantly different from zero.

Columns 3 and 4 introduce the government institutions variable to the model. The coefficient on this variable is significant at the 99 percent level and is negative, as expected (increases in the index indicate better institutional quality): more market-friendly and stable government institutions attract foreign capital, lowering the current account balance. ${ }^{8}$ The introduction of the government institutions variable does not, however, explain the U.S. current account deficit-the coefficient on the dummy variable remains large and significant.

Because only some of the sub-indexes in the composite indicator of government institutions may affect the current account balance, Table 3 presents some estimates of the model in which the sub-indexes are entered separately. Column 1 indicates that only two of the six indicators affect the current account balance negatively, and that these two indicators - the measures of the regulatory burden (measured so that increases in the index represent decreases in burden) and of the rule of law-are statistically significant. The significance of the regulatory burden measure is quite important, because of all the areas covered by the sub-indexes, relatively low regulatory burdens are often cited as the category in which the U.S. economy stands out, not only relative to developing countries, but relative to many industrial economies as well.

Nevertheless, as indicated by the coefficient on the U.S. dummy in column 2, even with the government institutions variable disaggregated into its component parts, the model still substantially overpredicts the U.S. current account deficit (although the error is less than without any governance indicators, as shown in Table 2, column 2). Columns 3 and 4 of Table 3 remove all of the subindexes except for the measure of regulatory burden, but this has little effect on the model.

\footnotetext{
${ }^{8}$ Chinn and Ito (2005) find similar results to hold, mainly of the high-income subset of their country dataset.
} 
Based on the model shown in Table 2, column 3, Figure 7 performs two functions: First, the lines connecting the squares and diamonds compare the model's prediction of the path of the U.S. current account with its actual values for all four periods; the model-fitted predictions are represented by black squares and the actual values by blue diamonds. (The results for the 1982-86 and 1987-91 periods are based on the coefficients estimated over the 1992-96 and 1997-2003 periods, with the institutions measure fixed at its 1992-96 period level and the fixed effect set to zero.)

Second, the multi-colored and textured columns decompose the model's prediction into the contributions of the different explanatory variables. Each bar in a column represents the value of an explanatory variable multiplied by its respective coefficient, with positive contributions plotted above the zero line and negative contributions below it. The fixed effect is included in the constant term, indicated by the green checkerboard bars. The effects of the financial crisis variable and its interaction term have been combined into a single contribution (blue cross-hatch), as have the effects of the youth and elderly dependency ratios (light blue horizontal lines). The sum of the contributions is equal to the model's predicted value, as positive and negative contributions net out.

The chart confirms that the model's predictions track neither the level of the U.S. deficit in the 1997-2003 period nor its deterioration from previous periods. The columns of contributions offer some insight into why the model cannot explain the deterioration of the U.S. deficit in the 1997-2003 period. First, the NFA (gray) and government institutions (wavy fuschia lines) variables do pull down the model's prediction of the current account balance, but only by about 3 percentage points of GDP; moreover, these variables change little between 1992-96 and 1997-2003. Second, the fiscal variable (peach dots) actually imparts a slight positive contribution to the predicted current account during the 1997-2003 period as the average U.S. fiscal balance at that time slightly 
exceeded the GDP-weighted sample average; deficits in the latter portion of the period were largely offset by surpluses in the earlier part. Third, in principle, the existence of financial crises outside the United States could lead the model to predict a larger deficit for the United States; in practice, the financial crisis variables (blue cross-hatch) imply a slightly stronger balance, owing both to the low U.S. openness ratio and the fact that the value of the financial crisis variable for the United States was quite small. Finally, the relative per capita income variable (solid pale blue) adds over 5 percentage points to the model's current account prediction, reflecting the United States' position as a very mature industrial economy.

Figure 8 repeats the same analysis as in Figure 7, but for a GDP-weighted average of the key Asian developing economies (excluding Singapore). The figure confirms that the model (again, Table 2, column 3) not only predicts the level of the developing Asian current account balance reasonably well in 1997-2003, but also tracks its upswing from the 1992-1996 period. As might be expected, the financial crisis variables account for much of that rise, as does the decline in the relative growth performance (green vertical lines) of the Asian economies.

Figure 9 extends the analysis across the individual Asian countries in the final 1997 - 2003 period. The model's predictions for the individual Asian countries is quite good, with the actual and predicted values often quite close to each other. The financial crisis variable contributes positively to the predicted balance in all cases, most notably in Malaysia where a high openness ratio adds to the impact. The contribution of the institutions variable is positive in China, Indonesia, and the Philippines, suggesting that the poor institutional environment in these countries supports capital outflows and therefore current account surpluses.

The last two columns of Figure 9 compare the predicted and actual current accounts for the Asian aggregate and the United States in 1997-2003. As has been noted earlier, the model predicts 
a considerably stronger current account for the United States -- one that is in slight surplus -- than actually occurred. Nevertheless, the model successfully predicts a weaker current account balance for the United States than for the Asian aggregate, despite the United States' much higher per capita income. This result is driven, among other factors, by the positive impact of slowing growth and the financial crisis on the Asian balances and the negative impact of institutional quality on the U.S. balance.

\section{Robustness to Alternative Specifications}

The remaining tables in the paper present estimates of the model under alternative specifications. The key features of the results shown in Tables 1 - 3 remain largely unchanged.

In Table 4, the net foreign asset position variable in the model is replaced by the average current account balance in the prior period. The results for most of the other coefficients, including on the dummy variables, are quite similar to those in Table 1, although far fewer coefficients are significantly different than zero. Notably, the coefficients on the financial crisis variables remain significant.

Tables 5a (using net foreign assets) and 5b (using lagged current accounts) present estimates that include Singapore in the sample. As indicated in Table 5a, including Singapore in the sample substantially reduces the size and significance of the financial crisis variables, likely reflecting Singapore’s extremely large and persistent current account surpluses over the past 11⁄2 decades, even as it has stayed out of financial crisis. However, in Table 5b, where the model includes lagged current account balances instead of net foreign asset positions, those variable are again significant.

In Table 6, the variable representing the change in output growth is replaced by the change in the growth of labor productivity (output per employee). Columns 1 and 2 present the model estimates for all four periods. As noted above, the coefficient on this variable fails to come in with 
the expected negative sign, and the model fails to explain the large U.S. current account deficit in 1997-2003. Columns 5 and 6 include the composite government institutions index and are estimated over just the last two periods. Comparing these estimates with those in columns 3 and 4 of Table 2, the growth variable is now significant, and the fit of the model is somewhat better. However, the large U.S. current account deficit remains unexplained, and the number of observations is substantially reduced owing to lack of data on employment for many countries.

\section{Conclusion}

Turning back to the review of the different proposed explanations for the global pattern of current account imbalances in Section II, our empirical work sheds light on several of these explanations.

First, our work provides support for at least half of the global savings glut hypothesis (\#5 above): the half suggesting that the U.S. deficit owes partly to an autonomous rise in the quantity of saving made available to the United States by its trading partners. In particular, our estimation results indicate that financial crises systematically lead to higher current account imbalances, and that the wave of crises that swept the developing world in the late 1990s, especially in East Asia, contributed to their shift into current account surplus.

This finding tends to undercut a related explanation for the East Asian surpluses (\#6 above), that they reflect the rational development strategy of East Asian governments and can be expected to persist for a long time as part of a "revived Bretton Woods system.” If keeping currencies competitive to achieve current account surpluses is good long-term development strategy, why did the East Asian economies wait until the late 1990s to start implementing this strategy, why did this implementation coincide so neatly with their financial crises, and why haven't economies in other regions in recent decades also adopted this strategy? In fact, our sense is that, with much of 
developing Asia's surpluses explained by prior financial crises, these surpluses will likely dissipate as adjustments following those crises are completed. This would restore the net flow of capital from industrial economies back to developing economies, consistent with standard theory.

Second, for the global saving glut story to explain the large U.S. current account deficit, however, some explanation must be posited for why the increase in global savings availability was tapped primarily by the United States. Our research provides mixed support for the explanations that have been advanced (some of which, in principle, could operate even without an autonomous rise in foreign saving). The expansion of the U.S. budget deficit (\#1, above) does not appear to explain the U.S. current account deficit, at least for the 1997-2003 period; not only is the estimated pass-through of the fiscal balance to the current account quite small, at about 0.1 , but the average budget balance during this period was relatively positive by international standards. The view that current account deficits can be caused both by strong economic performance (\#2, above) and by a market-friendly institutional environment (\#4, \#5) was well-supported by our research; we found that the pace of output growth generally exerted a significant negative effect on the current account balance, as did the quality of government institutions, particularly the regulatory regime. But even though the U.S. economy compared favorably to other economies along these dimensions, our model fails to explain the emergence of the large U.S. current account deficit.

The model's prediction for the United States is more successful in relative than in absolute terms. It is able to capture the weakness of the U.S. current account relative to that of the developing Asian countries, despite the pull of capital from mature industrial economies to developing economies identified by conventional theory. The financial crisis and deceleration of growth push up the model's prediction of developing Asia's current account, while the quality of U.S. institutions pushes down the model's prediction of the U.S. current account balance. 
How do we interpret the failure of our models to explain the widening of the U.S. external imbalance? At least two explanations are possible. First, it is possible that the model estimates of the relationships linking fiscal balances, economic growth, and institutional quality to the current account balance, which are based on the experiences of a wide range of countries over two decades, may understate the strength of these linkages in the United States in recent years. Second, the widening of the U.S. deficit may owe to other factors not included in the models. For example, the model does not contain a proxy for autonomous movements in consumption, as it difficult to think of a quantifiable variable that could capture such movements and which is available for a large number of countries. Thus, more research on this topic is clearly indicated.

\section{Data Appendix}

\begin{tabular}{|l|l|}
\hline \multicolumn{1}{|c|}{ Series } & Source \\
\hline $\begin{array}{l}\text { Current Account, Nominal GDP, Imports, and } \\
\text { Exports }\end{array}$ & IFS, OECD \\
\hline Exchange Rates & IFS \\
\hline Per Capita Income & World Development Indicators \\
\hline Employment & $\begin{array}{l}\text { Groningen Growth and Development Centre, } \\
\text { OECD }\end{array}$ \\
\hline Fiscal Balance & $\begin{array}{l}\text { GFS, OECD, Asian Development Bank, } \\
\text { MOF(Taiwan) }\end{array}$ \\
\hline Net Foreign Asset Position & Lane and Milesi-Ferretti (2001) \\
\hline Population Data & UN \\
\hline Indicators of Institutional Quality & Kaufmann, Kraay, and Mastruzzi (2005) \\
\hline Financial Crisis Indicators & Caprio and Klingbiel (2003) \\
\hline Oil: Imports, Exports, and Prices & $\begin{array}{l}\text { Energy Information Agency - Department of } \\
\text { Energy }\end{array}$ \\
\hline
\end{tabular}


Sample: Argentina, Australia, Austria, Bahrain, Bangladesh, Belgium, Bolivia, Brazil, Canada, Chile, China, Colombia, Costa Rica, Cyprus, Denmark, Dominican Republic, Egypt, El Salvador, Finland, France, Germany, Greece, Guatemala, Haiti, Honduras, Hong Kong, Iceland, India, Indonesian, Ireland, Israel, Italy, Japan, Jordan, South Korea, Malaysia, Mexico, Netherlands, New Zealand, Norway, Oman, Pakistan, Panama, Paraguay, Peru, Philippines, Portugal, Singapore, South Africa, Spain, Sri Lanka, Sweden, Switzerland, Syria, Taiwan, Thailand, Turkey, United Kingdom, United States, Venezuela.

\section{REFERENCES}

Ahearne, Alan, William Griever, and Frank Warnock (2004), “Information Costs and Home Bias,” Journal of International Economics, vol.62, pp. 313-336.

Bernanke, Ben S. (2005), “The Global Saving Glut and the U.S. Current Account Deficit,” Homer Jones Lecture, St. Louis, Missouri, April 14.

http://www.federalreserve.gov/boarddocs/speeches/2005/20050414/default.htm

Blanchard, Olivier and Francesco Giavazzi (2002), "Current Account Deficits in the Euro Area: The End of the Feldstein-Horioka Puzzle?” Brookings Papers on Economic Activity, pp. 147-209.

Blanchard, Olivier, Francesco Giavazzi, and Filipa Sa (2005), “The U.S. Current Account and the Dollar,” NBER Working Paper No. 11137, February.

Bussiere, Matthieu, Marcel Fratzscher and Gernot J. Muller (2004), “Current Account Dynamics in OECD and EU Acceding Countries - An Intertemporal Approach,” European Central Bank Working Paper Series No. 311, February.

(2005), "Productivity Shocks, Budget Deficits and the Current Account," European Central Bank Working Paper Series No. 509, August.

Caprio, Gerard. and Daniela Klingebiel (2003), "Episodes of Systemic and Borderline Financial Crisis,” World Bank Working Paper.

Chinn, Menzie D. and Eswar S. Prasad (2003), "Medium-term Determinants of Current Accounts in Industrial and Developing Countries: An Empirical Exploration,” Journal of International Economics Vol. 59, pp.47-76.

Chinn, Menzie D. (2004), “Incomes, Exchange Rates and the U.S. Trade Deficit, Once Again,” International Finance Vol. 7, No. 3, pp. 451-469.

Chinn, Menzie D. (2005), “Getting Serious about the Twin Deficits,” Council on Foreign Relations Special Report, forthcoming. 
Chinn, Menzie D. and Hiro Ito (2005), "Current Account Balances, Financial Development, and Institutions: Assaying the World 'Savings Glut', 'La Follette School Working Paper No. 2005-023. October.

Cline, William R. (2005), The United States as a Debtor Nation: Risks and Policy Reform, Institute for International Economics, Washington D.C.

Dooley, Michael P., David Folkerts-Landau, and Peter Garber (2003), “An Essay on the Revived Bretton Woods System,” NBER Working Paper 9971, September.

(2004), "Direct Investment, Rising Real Wages and the Absorption of Excess Labor in the Periphery,” NBER Working Paper 10626, July.

Erceg, Christopher J., Luca Guerrieri and Christopher Gust (2005a), “Expansionary Fiscal Shocks and the Current Account,” Board of Governors of the Federal Reserve System, International Finance Discussion Papers No. 825, January.

(2005b), “SIGMA: A New Open Economy Model for Policy Analysis,” Board of Governors of the Federal Reserve System, International Finance Discussion Papers No. 835, July.

Edwards, Sebastian (2005), "Is the U.S. Current Account Deficit Sustainable? And If Not, How Costly is Adjustment Likely to Be?” NBER Working Paper 11541, August.

Ferguson, Roger W. (2005), “U.S. Current Account Deficit: Causes and Consequences,” speech to Economics Club of the University of North Carolina, Chapel Hill, North Carolina, April 20. http://www.federalreserve.gov/boarddocs/speeches/2005/20050420/default.htm

Frankel, Jeffrey and Andrew Rose (1996), “Currency Crashes in Emerging Markets: An Empirical Treatment,” Journal of International Economics vol. 41, November, pp. 351-66.

Glick, Reuven and Kenneth Rogoff (1995), “Global versus Country-Specific Productivity Shocks and the Current Account,” Journal of Monetary Economics Vol. 35, pp .159-192.

Gramlich, Edward M. (2004), "Budget and Trade Deficits: Linked, Both Worrisome in the Long Run, but not Twins,” speech to National Association for Business Economics, Los Angeles, California, March 31. http://www.federalreserve.gov/boarddocs/speeches/2004/20040225/default.htm

Greenspan, Alan (2003), “Current Account,” speech to $21^{\text {st }}$ Annual Monetary Policy Conference, Cato Institute, Washington D.C., November 20. http://www.federalreserve.gov/boarddocs/speeches/2003/200311230/default.htm

Gruber, Joseph W. (2004), “Increased Current Account Dispersion, Differential Growth, 
Demographic Dispersion, or Greater Financial Integration?” unpublished paper, Board of Governors of the Federal Reserve System, December.

Gruber, Joseph W. (2004), “A Present Value Test of Habits and the Current Account,” Journal of Monetary Economics Vol. 51, pp.1495-1507.

Kamin, Steven B. (2005), “The Revived Bretton Woods System: Does It Explain Developments in Non-China Developing Asia?” paper presented at Federal Reserve Bank of San Francisco conference, "The Revived Bretton Woods System: A New Paradigm for Asian Development?”, February 4. http://www.frbsf.org/economics/conferences/0502/kamin.pdf

Kaminsky, Graciela, Saul Lizondo, and Carmen Reinhart (1998), "Leading Indicators of Currency Crises," IMF Staff Papers, Vol. 45, pp. 1-48.

Kaufmann, Daniel, Aart Kraay, and Massimo Mastruzzi (2005), "Governance Matters IV: Governance Indicators for 1996 - 2004,” World Bank Policy Research Working Paper 3630, May.

Lane, Philip and Giles Milesi-Ferretti (2006), "The External Wealth of Nations Mark II: Revised and Extended Estimates of Foreign Assets and Liabilities, 1970 - 2004,” Institute for International Integration Studies working paper No. 126.

Mann, Catherine L. (1999), Is the U.S. Trade Deficit Sustainable? Institute For International Economics, Washington, D.C. (2002), "Perspectives on the U.S. Current Account Deficit and Sustainability,” Journal of Economic Perspectives 16, 131-152. (2004), "Managing Exchange Rates: Achievement of Global Re-balancing or Evidence of Global Co-dependency?” Business Economics, July.

Roubini, Nouriel and Brad Setser (2004), "The US as a Net Debtor: The Sustainability of the US External Imbalances,” unpublished working paper, November.

Truman, Edwin M. (2004), "Budget and External Deficits: Not Twins but the Same Family,” paper presented at the Federal Reserve Bank of Boston Annual Research Conference, June 14-16. 
Table 1: Main Results

Per Capita GDP

\begin{tabular}{lllll}
1 & 2 & 3 & 4 & 5 \\
\hline $\mathbf{0 . 0 1 2}$ & $\mathbf{0 . 0 1 3}$ & $\mathbf{0 . 0 1 2}$ & $\mathbf{0 . 0 1 4}$ & $\mathbf{0 . 0 1 3}$
\end{tabular}

$\Delta$ Growth

3.073

0.013

0.012

0.014

0.013

$\Delta$ Growth

$-0.095$

2.830

3.072

2.718

2.969

Fiscal Balance

$-1.211$

$-0.167$

$-0.280$

$-0.003$

0.018

NFA

1.688

0.115

0.119

$-0.040$

0.119

0.018

2.220

1.998

0.116

2.077

0.021

0.024

1.733

Youth Ratio

$-0.032$

2.392

2.413

$-0.014$

$-2.623$

Elderly Ratio

$-0.135$

$-2.294$

Openness

0.008

1.308

Oil Balance

0.089

$-0.679$

$-0.096$

$-1.870$

$-0.022$

$-1.364$

$\mathbf{0 . 0 2 4} \mathbf{0 . 0 2 4}$

$2.599 \quad 2.416$

$-0.015 \quad-0.021$

$-0.758-1.388$

$\begin{array}{lll}-0.114 & -0.111 & -0.120\end{array}$

$\begin{array}{lll}-2.351 & -2.343 & -2.538\end{array}$

$\begin{array}{llll}0.003 & \mathbf{0 . 0 1 2} & \mathbf{0 . 0 1 0} & \mathbf{0 . 0 1 2}\end{array}$

0.410

3.442

2.655

3.183

0.085

0.081

0.080

0.079

5.301

5.131

4.630

4.449

4.653

$-0.021$

$-0.027$

$-0.022$

$-2.253$

0.069

$-2.598$

$-2.501$

Fin. Crisis ${ }^{*}$ Openness

4.764

$\mathbf{0 . 0 7 0} \quad \mathbf{0 . 0 7 0}$

0.041

2.149

2.555

4.901

China(1997 - 2003)

0.016

0.032

1.597

0.033

0.874

0.378

0.032

$\mathbf{0 . 0 5 3}$

1.823

3.754

0.026

0.001

1.216

0.059

0.098

$-0.009$

3.169

$-0.177$

0.062

0.026

10.606

1.618

0.036

0.024

0.428

0.297

$\mathbf{0 . 0 8 2}$

0.034

2.706

0.929

$-0.045$

$-0.050$

$-2.883$

$-0.051$

$-2.724$

$-3.102$

\#Obs

234

0.286

234

234

234

234

$\mathrm{R}^{\wedge} 2$

0.030

0.339

0.351

0.348

0.357

SER

0.029

0.029

0.029

0.029

Panel regression with unreported constant and period fixed effects.

59 cross-sections and 4 periods.

t-statistic reported underneath coefficient

Bold indicates signifance at the 10 percent level. 
Table 2: The Model with Governance Indicators

Per Capita GDP

\begin{tabular}{llll}
1 & 2 & 3 & 4 \\
\hline $\mathbf{0 . 0 1 8}$ & $\mathbf{0 . 0 1 9}$ & $\mathbf{0 . 0 2 5}$ & $\mathbf{0 . 0 2 7}$ \\
3.562 & 3.228 & 3.612 & 3.365
\end{tabular}

$\Delta$ Growth

$-0.185$

$-0.179$

$-0.158$

$-0.153$

$-2.189$

$-2.013$

$-1.491$

Fiscal Balance

0.153

0.157

0.171

$-1.399$

NFA

0.019

3.984

3.354

0.019

2.829

2.827

0.013

1.959

0.173

Youth Ratio

$-0.006$

$-0.008$

$-0.043$

$-0.254$

$-0.365$

$-2.457$

3.555

Elderly Ratio

$-0.070$

$-1.122$

$-0.092$

$-0.049$

$-1.230$

$-0.739$

0.013

1.990

Openness

0.009

0.007

0.015

1.960

1.781

3.007

0.072

0.092

$-0.043$

$-2.581$

Oil Balance

2.529

2.700

3.380

$-0.018$

$-4.027$

$-0.071$

$-0.875$

Gov. Institutions

$-4.057$

Fin. Crisis

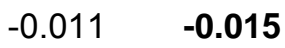

$-0.023$

$-3.524$

0.013

3.006

0.087

3.681

$-0.018$

$-4.057$

$-1.521$

$-2.568$

$-0.025$

$-4.373$

Fin. Crisis ${ }^{\star}$ Openness

$\mathbf{0 . 0 6 3}$

0.066

0.069

0.072

4.807

5.351

5.744

6.181

$-0.058$

$-0.055$

$-3.562$

$-3.595$

\#Obs

$\mathrm{R}^{\wedge} 2$

117

0.455

117

117

117

SER

0.027

0.473

0.479

0.494

0.027

0.026

0.026

Panel regression with unreported constant and period fixed effects.

59 cross-sections and 2 periods.

t-statistic reported underneath coefficient

Bold indicates signifance at the 10 percent level. 
Table 3:The Model with Governance Indicators - Disaggregated

\begin{tabular}{|c|c|c|c|c|}
\hline \multirow{3}{*}{ Per Capita GDP } & 1 & 2 & 3 & 4 \\
\hline & 0.020 & 0.022 & 0.022 & 0.023 \\
\hline & 3.552 & 3.209 & 5.629 & 4.872 \\
\hline \multirow[t]{2}{*}{$\Delta$ Growth } & -0.231 & -0.222 & -0.212 & -0.205 \\
\hline & -1.744 & -1.662 & -1.608 & -1.548 \\
\hline \multirow[t]{2}{*}{ Fiscal Balance } & 0.095 & 0.099 & 0.124 & 0.128 \\
\hline & 1.447 & 1.551 & 2.013 & 2.187 \\
\hline \multirow[t]{2}{*}{ NFA } & 0.014 & 0.014 & 0.013 & 0.014 \\
\hline & 2.263 & 2.332 & 2.088 & 2.105 \\
\hline \multirow[t]{2}{*}{ Youth Ratio } & -0.040 & -0.041 & -0.043 & -0.043 \\
\hline & -1.878 & -1.994 & -2.244 & -2.300 \\
\hline \multirow[t]{2}{*}{ Elderly Ratio } & -0.089 & -0.108 & -0.060 & -0.079 \\
\hline & -2.028 & -2.050 & -1.218 & -1.344 \\
\hline \multirow[t]{2}{*}{ Openness } & 0.018 & 0.015 & 0.017 & 0.015 \\
\hline & 2.837 & 2.936 & 3.358 & 3.387 \\
\hline \multirow[t]{2}{*}{ Oil Balance } & 0.072 & 0.068 & 0.077 & 0.072 \\
\hline & 1.920 & 2.078 & 2.517 & 2.677 \\
\hline \multirow[t]{2}{*}{ Fin. Crisis } & -0.014 & -0.018 & -0.018 & -0.021 \\
\hline & -1.582 & -2.407 & -3.809 & -6.575 \\
\hline \multirow[t]{2}{*}{ Fin. Crisis*Openness } & 0.058 & 0.061 & 0.064 & 0.066 \\
\hline & 2.832 & 3.119 & 4.255 & 4.611 \\
\hline \multirow[t]{2}{*}{ Voice } & 0.002 & 0.002 & & \\
\hline & 0.867 & 0.660 & & \\
\hline \multirow[t]{2}{*}{ Stability } & 0.004 & 0.004 & & \\
\hline & 0.675 & 0.699 & & \\
\hline \multirow[t]{2}{*}{ Gov. Eff. } & 0.014 & 0.014 & & \\
\hline & 1.657 & 1.649 & & \\
\hline \multirow[t]{2}{*}{ Regulatory } & -0.029 & -0.027 & -0.020 & -0.019 \\
\hline & -5.653 & -6.033 & -4.968 & -5.536 \\
\hline \multirow[t]{2}{*}{ Rule of Law } & -0.012 & -0.012 & & \\
\hline & -1.784 & -1.698 & & \\
\hline \multirow[t]{2}{*}{ Corruption } & 0.003 & 0.002 & & \\
\hline & 0.278 & 0.183 & & \\
\hline \multirow[t]{2}{*}{ US(Q4) } & & -0.049 & & -0.050 \\
\hline & & -6.246 & & -4.327 \\
\hline \#Obs & 117 & 117 & 117 & 117 \\
\hline $\mathrm{R}^{\wedge} 2$ & 0.486 & 0.497 & 0.498 & 0.510 \\
\hline SER & 0.026 & 0.026 & 0.026 & 0.026 \\
\hline
\end{tabular}

Panel regression with unreported constant and period fixed effects. 59 cross-sections and 2 periods.

t-statistic reported underneath coefficient

Bold indicates signifance at the 10 percent level. 
Table 4: The Model with Lagged Current Accounts

\begin{tabular}{|c|c|c|c|c|}
\hline & 1 & 2 & 3 & 4 \\
\hline \multirow{2}{*}{ Per Capita GDP } & 0.008 & 0.009 & 0.009 & 0.010 \\
\hline & 1.528 & 1.512 & 1.628 & 1.560 \\
\hline \multirow[t]{2}{*}{$\Delta$ Growth } & -0.152 & -0.076 & -0.091 & -0.075 \\
\hline & -1.684 & -0.845 & -1.082 & -0.837 \\
\hline \multirow[t]{2}{*}{ Fiscal Balance } & 0.072 & 0.069 & 0.071 & 0.068 \\
\hline & 1.340 & 1.507 & 1.422 & 1.494 \\
\hline \multirow[t]{2}{*}{$\mathrm{CA}(-1)$} & 0.437 & 0.463 & 0.485 & 0.481 \\
\hline & 2.268 & 2.400 & 2.599 & 2.513 \\
\hline \multirow[t]{2}{*}{ Youth Ratio } & -0.032 & -0.017 & -0.025 & -0.019 \\
\hline & -1.688 & -0.714 & -1.287 & -0.815 \\
\hline \multirow[t]{2}{*}{ Elderly Ratio } & -0.106 & -0.073 & -0.096 & -0.090 \\
\hline & -1.432 & -1.139 & -1.593 & -1.522 \\
\hline \multirow[t]{2}{*}{ Openness } & 0.012 & 0.007 & 0.017 & 0.014 \\
\hline & 1.720 & 0.967 & 3.873 & 2.629 \\
\hline \multirow[t]{2}{*}{ Oil Balance } & 0.042 & 0.038 & 0.032 & 0.033 \\
\hline & 1.154 & 0.984 & 0.862 & 0.847 \\
\hline \multirow[t]{2}{*}{ Fin. Crisis } & & & -0.026 & -0.029 \\
\hline & & & -2.609 & -3.051 \\
\hline \multirow[t]{2}{*}{ Fin. Crisis ${ }^{*}$ Openness } & & & 0.073 & 0.069 \\
\hline & & & 3.994 & 2.375 \\
\hline \multirow[t]{2}{*}{ China(1997 - 2003) } & & 0.029 & & 0.022 \\
\hline & & 1.846 & & 1.151 \\
\hline \multirow[t]{2}{*}{ Hong Kong(1997-2003) } & & 0.013 & & 0.030 \\
\hline & & 0.298 & & 0.820 \\
\hline \multirow[t]{2}{*}{ Indonesia(1997 - 2003) } & & 0.045 & & 0.025 \\
\hline & & 2.164 & & 1.020 \\
\hline \multirow[t]{2}{*}{ Korea(1997 - 2003) } & & 0.029 & & 0.007 \\
\hline & & 1.288 & & 0.270 \\
\hline \multirow[t]{2}{*}{ Malaysia(1997 - 2003) } & & 0.103 & & -0.001 \\
\hline & & 2.406 & & -0.020 \\
\hline \multirow[t]{2}{*}{ Phil(1997 - 2003) } & & 0.062 & & 0.028 \\
\hline & & 10.051 & & 1.480 \\
\hline \multirow[t]{2}{*}{ Taiwan(1997 - 2003) } & & 0.028 & & 0.018 \\
\hline & & 0.429 & & 0.277 \\
\hline \multirow[t]{2}{*}{ Thailand(1997 - 2003) } & & 0.090 & & 0.044 \\
\hline & & 3.989 & & 1.382 \\
\hline \multirow[t]{2}{*}{ U.S.(1997 - 2003) } & & -0.037 & & -0.042 \\
\hline & & -2.704 & & -3.056 \\
\hline \#Obs & 238 & 238 & 238 & 238 \\
\hline$R^{\wedge} 2$ & 0.401 & 0.457 & 0.470 & 0.467 \\
\hline SER & 0.028 & 0.027 & 0.026 & 0.026 \\
\hline
\end{tabular}

Panel regression with unreported constant and period fixed effects.

60 cross-sections and 4 periods.

$\mathrm{t}$-statistic reported underneath coefficient

Bold indicates signifance at the 10 percent level. 
Table 5a: The Model Including Singapore with NFA Positions

Per Capita GDP

$\Delta$ Growth

Fiscal Balance

NFA

Youth Ratio

Elderly Ratio

Openness

Oil Balance

Fin. Crisis

Fin. Crisis*Openness

China(1997 - 2003)

Hong Kong(1997-2003)

Indonesia(1997 - 2003)

Korea(1997 - 2003)

Malaysia(1997 - 2003)

Phil(1997 - 2003)

Singapore(1997-2003)

Taiwan(1997 - 2003)

Thailand(1997 - 2003)

U.S.(1997 - 2003)

\#Obs

$\mathrm{R}^{\wedge} 2$

SER

\begin{tabular}{llll}
1 & 2 & 3 & 4 \\
\hline $\mathbf{0 . 0 1 2}$ & $\mathbf{0 . 0 1 3}$ & $\mathbf{0 . 0 1 3}$ & $\mathbf{0 . 0 1 4}$
\end{tabular}

$\begin{array}{llll}2.920 & 2.833 & 2.961 & 2.788\end{array}$

$\begin{array}{llll}-0.117 & -0.019 & -0.062 & -0.012\end{array}$

$\begin{array}{llll}-1.381 & -0.254 & -0.856 & -0.151\end{array}$

$\begin{array}{llll}0.153 & 0.146 & 0.163 & 0.149\end{array}$

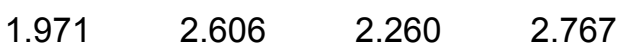

$\begin{array}{llll}0.019 & 0.021 & 0.023 & 0.022\end{array}$

$\begin{array}{llll}1.922 & 2.304 & 2.346 & 2.351\end{array}$

$\begin{array}{llll}-0.030 & -0.016 & -0.021 & -0.016\end{array}$

$\begin{array}{llll}-2.815 & -0.819 & -1.566 & -0.807\end{array}$

$\begin{array}{llll}-0.141 & -0.106 & -0.120 & -0.109\end{array}$

$\begin{array}{llll}-2.524 & -2.305 & -2.545 & -2.349\end{array}$

$\begin{array}{llll}\mathbf{0 . 0 1 5} & 0.008 & \mathbf{0 . 0 1 9} & \mathbf{0 . 0 1 1}\end{array}$

$\begin{array}{llll}2.662 & 1.547 & 3.376 & 2.640\end{array}$

$\begin{array}{llll}\mathbf{0 . 0 8 8} & 0.086 & 0.082 & 0.084\end{array}$

$\begin{array}{llll}4.889 & 4.697 & 4.353 & 4.280\end{array}$

$-0.004-0.008$

$-0.391 \quad-0.796$

$\mathbf{0 . 0 3 8} \quad 0.030$

$2.407 \quad 1.137$

0.035

1.900

0.011

0.295

0.040

2.306

0.010

0.452

0.041

0.791

0.042

2.766

0.150

2.504

0.028

0.353

0.055

1.427

$\begin{array}{ll}-0.044 & -0.045 \\ -2.999 & -3.086\end{array}$

$\begin{array}{ll}-0.044 & -0.045 \\ -2.999 & -3.086\end{array}$

$\begin{array}{rrrr}238 & 238 & 238 & 238 \\ 0.363 & 0.436 & 0.387 & 0.434 \\ 0.032 & 0.030 & 0.031 & 0.030\end{array}$

Panel regression with unreported constant and period fixed effects. 60 cross-sections and 4 periods. t-statistic reported underneath coefficient Bold indicates signifance at the 10 percent level. 
Table 5b: The Model Including Singapore with Lagged CA

Per Capita GDP

$\Delta$ Growth

Fiscal Balance

$\mathrm{CA}(-1)$

Youth Ratio

Elderly Ratio

Openness

Oil Balance

Fin. Crisis

Fin. Crisis*Openness

China(1997 - 2003)

Hong Kong(1997-2003)

Indonesia(1997 - 2003)

Korea(1997 - 2003)

Malaysia(1997 - 2003)

Phil(1997 - 2003)

Singapore(1997-2003)

Taiwan(1997 - 2003)

Thailand(1997 - 2003)

U.S.(1997 - 2003)

\begin{tabular}{|c|c|c|c|c|}
\hline & 1 & 2 & 3 & 4 \\
\hline \multirow{2}{*}{ Per Capita GDP } & 0.007 & 0.009 & 0.008 & 0.010 \\
\hline & 1.444 & 1.477 & 1.511 & 1.507 \\
\hline \multirow[t]{2}{*}{$\Delta$ Growth } & -0.167 & -0.083 & -0.120 & -0.082 \\
\hline & -1.824 & -0.919 & -1.454 & -0.909 \\
\hline \multirow{2}{*}{ Fiscal Balance } & 0.095 & 0.093 & 0.103 & 0.096 \\
\hline & 1.620 & 2.003 & 1.941 & 2.172 \\
\hline \multirow{2}{*}{$\mathrm{CA}(-1)$} & 0.489 & 0.477 & 0.542 & 0.495 \\
\hline & 2.890 & 2.579 & 3.250 & 2.653 \\
\hline \multirow[t]{2}{*}{ Youth Ratio } & -0.030 & -0.018 & -0.024 & -0.019 \\
\hline & -1.697 & -0.849 & -1.287 & -0.895 \\
\hline \multirow[t]{2}{*}{ Elderly Ratio } & -0.107 & -0.080 & -0.095 & -0.090 \\
\hline & -1.502 & -1.343 & -1.596 & -1.573 \\
\hline \multirow[t]{2}{*}{ Openness } & 0.016 & 0.011 & 0.022 & 0.016 \\
\hline & 3.429 & 2.622 & 5.046 & 5.470 \\
\hline \multirow[t]{2}{*}{ Oil Balance } & 0.034 & 0.035 & 0.023 & 0.032 \\
\hline & 0.968 & 0.927 & 0.649 & 0.814 \\
\hline \multirow[t]{2}{*}{ Fin. Crisis } & & & -0.017 & -0.018 \\
\hline & & & -1.862 & -2.178 \\
\hline \multirow[t]{2}{*}{ Fin. Crisis*Openness } & & & 0.057 & 0.045 \\
\hline & & & 3.246 & 1.842 \\
\hline \multirow[t]{2}{*}{ China(1997 - 2003) } & & 0.029 & & 0.023 \\
\hline & & 1.847 & & 1.331 \\
\hline \multirow[t]{2}{*}{ Hong Kong(1997-2003) } & & 0.002 & & 0.013 \\
\hline & & 0.040 & & 0.357 \\
\hline \multirow[t]{2}{*}{ Indonesia(1997 - 2003) } & & 0.044 & & 0.030 \\
\hline & & 2.092 & & 1.220 \\
\hline \multirow[t]{2}{*}{ Korea(1997 - 2003) } & & 0.027 & & 0.011 \\
\hline & & 1.219 & & 0.438 \\
\hline \multirow[t]{2}{*}{ Malaysia(1997 - 2003) } & & 0.097 & & 0.027 \\
\hline & & 2.194 & & 0.488 \\
\hline \multirow[t]{2}{*}{ Phil(1997 - 2003) } & & 0.061 & & 0.037 \\
\hline & & 10.089 & & 2.248 \\
\hline \multirow[t]{2}{*}{ Singapore(1997-2003) } & & 0.081 & & 0.093 \\
\hline & & 1.936 & & 2.061 \\
\hline \multirow[t]{2}{*}{ Taiwan(1997 - 2003) } & & 0.026 & & 0.018 \\
\hline & & 0.405 & & 0.295 \\
\hline \multirow[t]{2}{*}{ Thailand(1997 - 2003) } & & 0.087 & & 0.057 \\
\hline & & 3.656 & & 1.767 \\
\hline \multirow[t]{2}{*}{ U.S.(1997 - 2003) } & & -0.035 & & -0.038 \\
\hline & & -2.904 & & -3.238 \\
\hline \#Obs & 242 & 242 & 242 & 242 \\
\hline $\mathrm{R}^{\wedge} 2$ & 0.495 & 0.544 & 0.533 & 0.546 \\
\hline SER & 0.028 & 0.027 & 0.027 & 0.027 \\
\hline
\end{tabular}

Panel regression with unreported constant and period fixed effects. t-statistic reported underneath coefficient. 61 cross-sections and 4 periods. Bold indicates signifance at the 10 percent level. 
Table 6: The Model Controlling for Employment Growth

Per Capita GDP

$\Delta$ Growth per Employee

Fiscal Balance

NFA

Youth Ratio

Elderly Ratio

Openness

Oil Balance

Gov. Institutions

Fin. Crisis

Fin. Crisis*Openness

U.S.(1997 - 2003)

\#Obs

$\mathrm{R}^{\wedge} 2$

SER

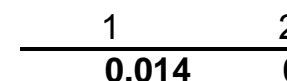

$4.571 \quad 4.483$

$0.003 \quad 0.012$

$0.024 \quad 0.096$

0.054

0.708

0.053

0.721

$\mathbf{0 . 0 3 4}$

2.063

$-0.018$

$-1.631$

$-0.213$

$-3.286$

0.035

2.073

$-0.017$

$-1.550$

$-0.219$

$-3.208$

0.012

1.493

0.172

4.323

0.011

1.383

0.171

4.265
3 4.687

0.060

0.630

0.074

0.943

$\mathbf{0 . 0 4 2}$

2.590

$-0.007$

$-0.625$

$-0.172$

$-3.741$

0.014

2.346

0.159

4.844
4

4.511

0.068

0.714

0.073

0.962

$\mathbf{0 . 0 4 2}$

2.596

$-0.006$

$-0.579$

$-0.179$

$-3.846$

0.013

2.167

0.157

4.838

$-0.019$

$-1.903$

0.062

3.269

$-0.052$

$-2.743$

$\begin{array}{rr}186 & 186 \\ 0.364 & 0.372 \\ 0.029 & 0.029\end{array}$

186

0.029

186
0.423
0.027

$-0.020$

$-2.179$

0.063

3.391

$-0.054$

$-2.724$

\begin{tabular}{ll}
5 & 6 \\
\hline $\mathbf{0 . 0 2 4}$ & $\mathbf{0 . 0 2 5}$
\end{tabular}

$3.317 \quad 3.183$

$\begin{array}{ll}-0.210 & -0.197\end{array}$

$-2.110 \quad-2.156$

$0.052 \quad 0.053$

$0.525 \quad 0.523$

$0.026 \quad 0.027$

$3.531 \quad 3.426$

$-0.010 \quad-0.012$

$-0.538 \quad-0.673$

$\begin{array}{ll}-0.111 & -0.137\end{array}$

$-4.771 \quad-3.441$

$0.014 \quad 0.012$

$1.938 \quad 1.832$

$0.206 \quad 0.203$

$6.029 \quad 6.074$

$-0.008 \quad-0.008$

$-0.902 \quad-0.825$

$-0.009 \quad-0.013$

$-0.854 \quad-1.436$

$0.060 \quad 0.063$

$3.399 \quad 3.891$

$-0.054$

$-2.986$

Panel regression with unreported constant and period fixed effects.

47 cross-sections and 4 Periods

t-statistic reported underneath coefficient

Bold indicates signifance at the 10 percent level. 


\section{Figure 1: Current Accounts}

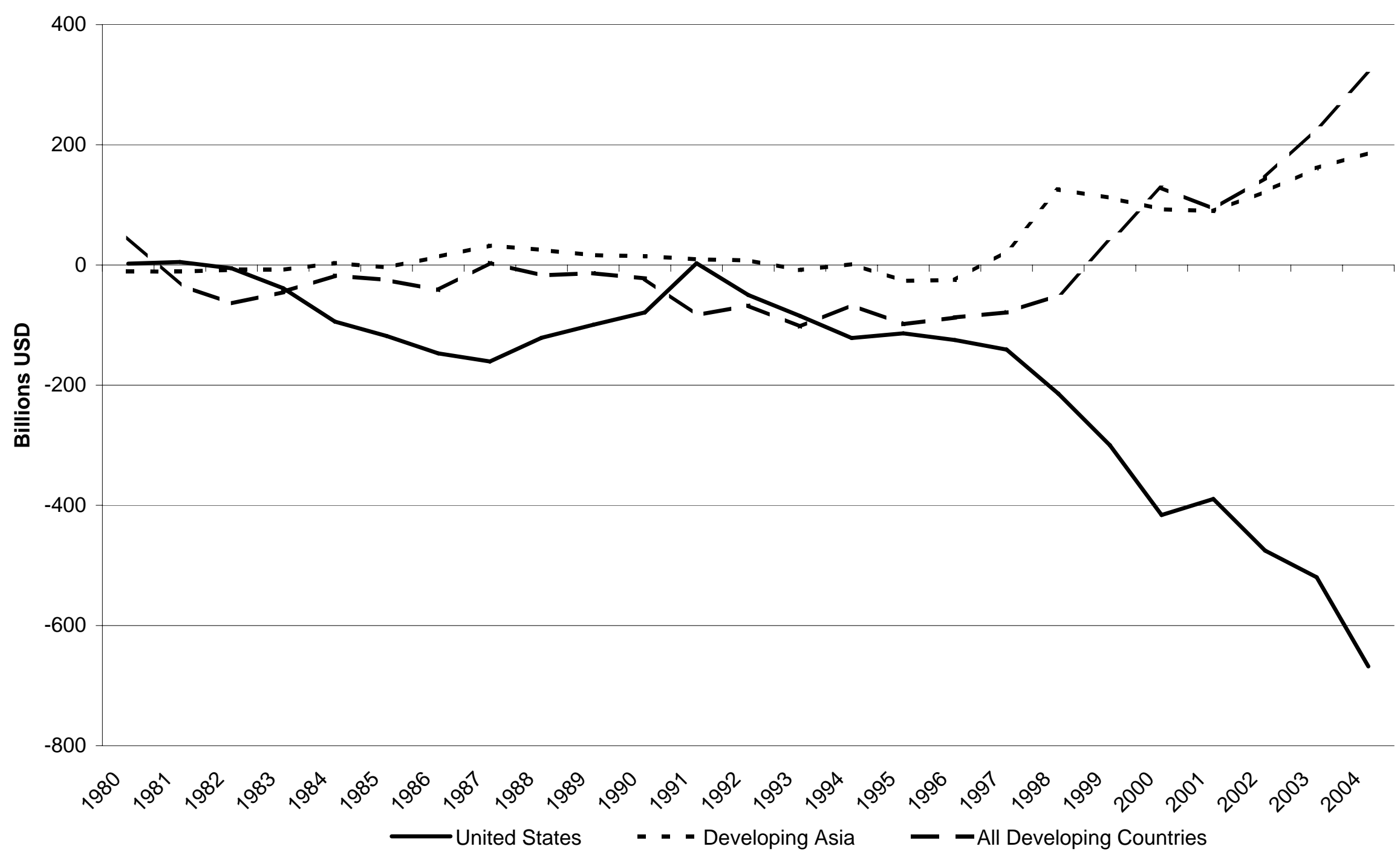

Source: IMF - WEO 
Figure 2: Ratio of Absolute Sum of Current Accounts to Sum of GDP

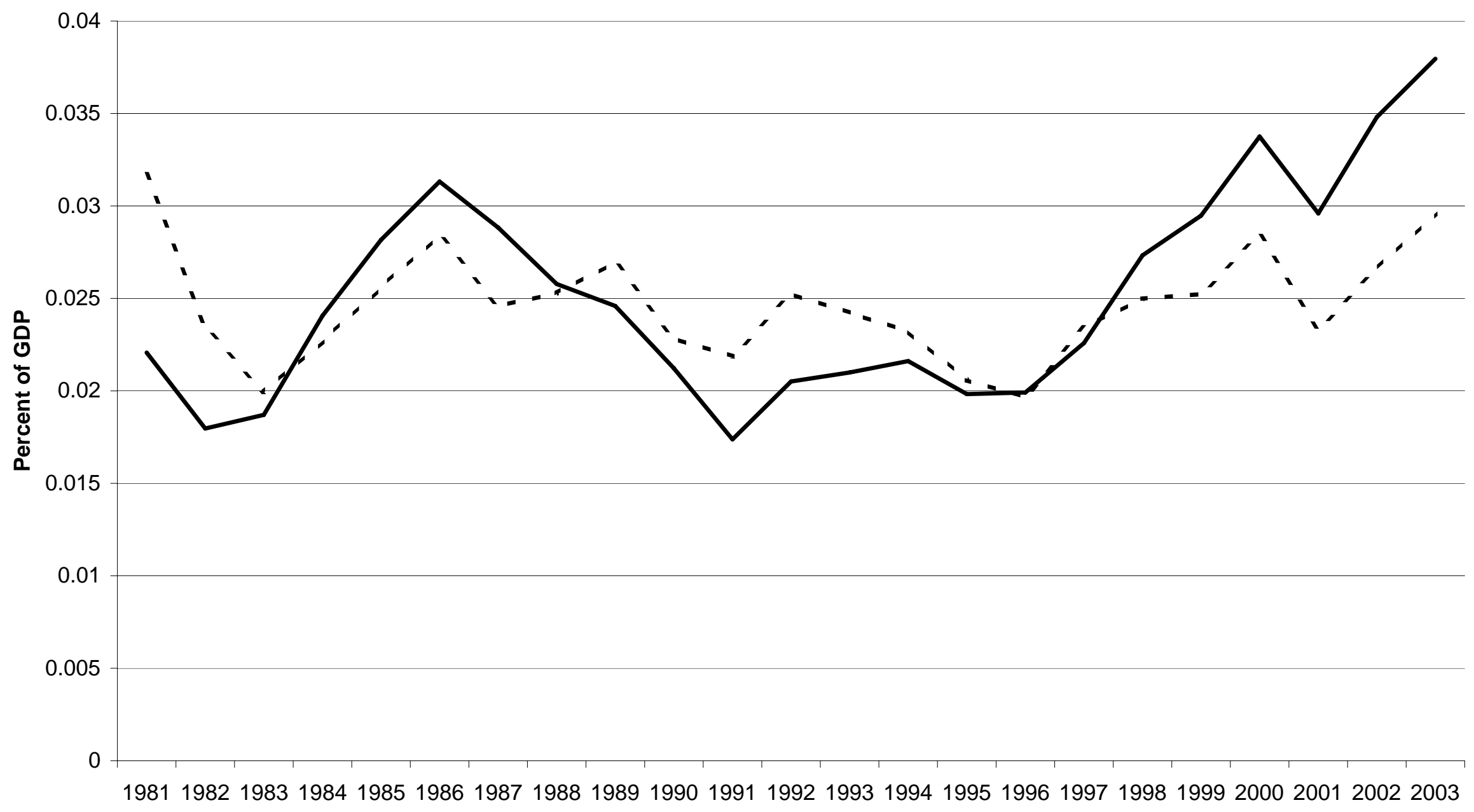

—World - - - Ex - United States and Developing Asia 


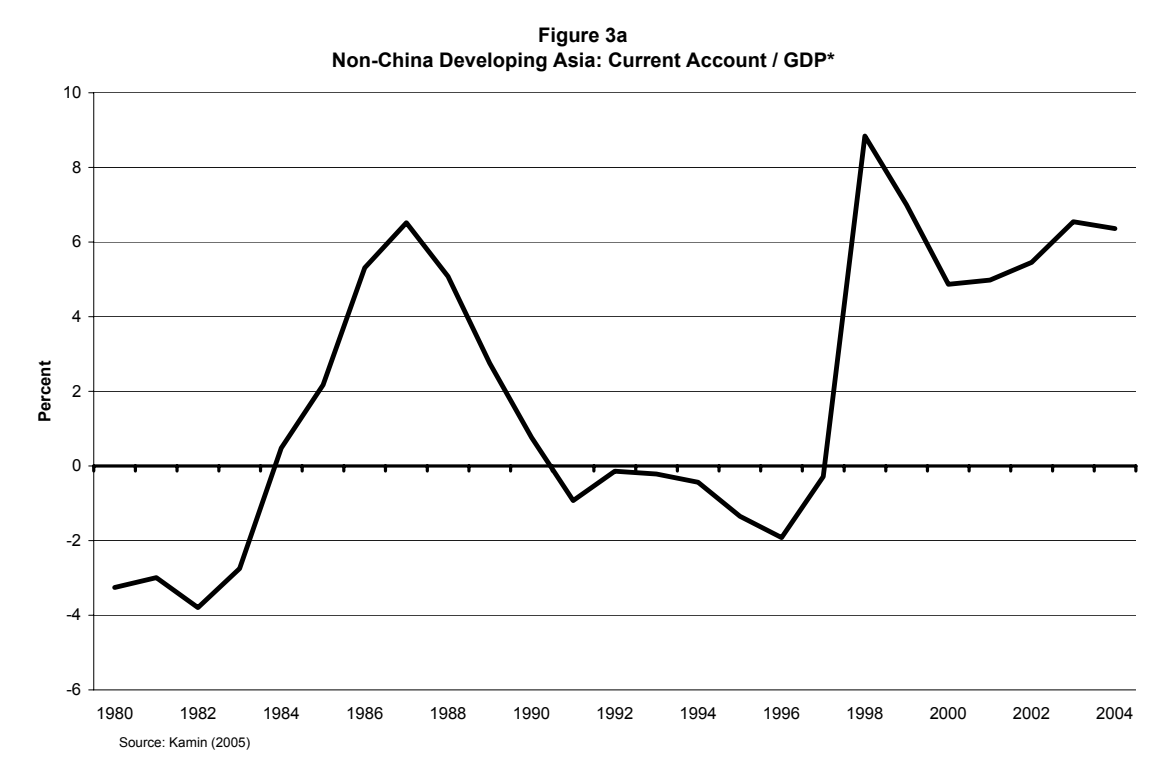

"2004 current account data is based on national sources for Korea, Singapore, and Thailand; and September 2004 IMF WEO Database for all else. 2004

$\stackrel{\omega}{\hookrightarrow}$

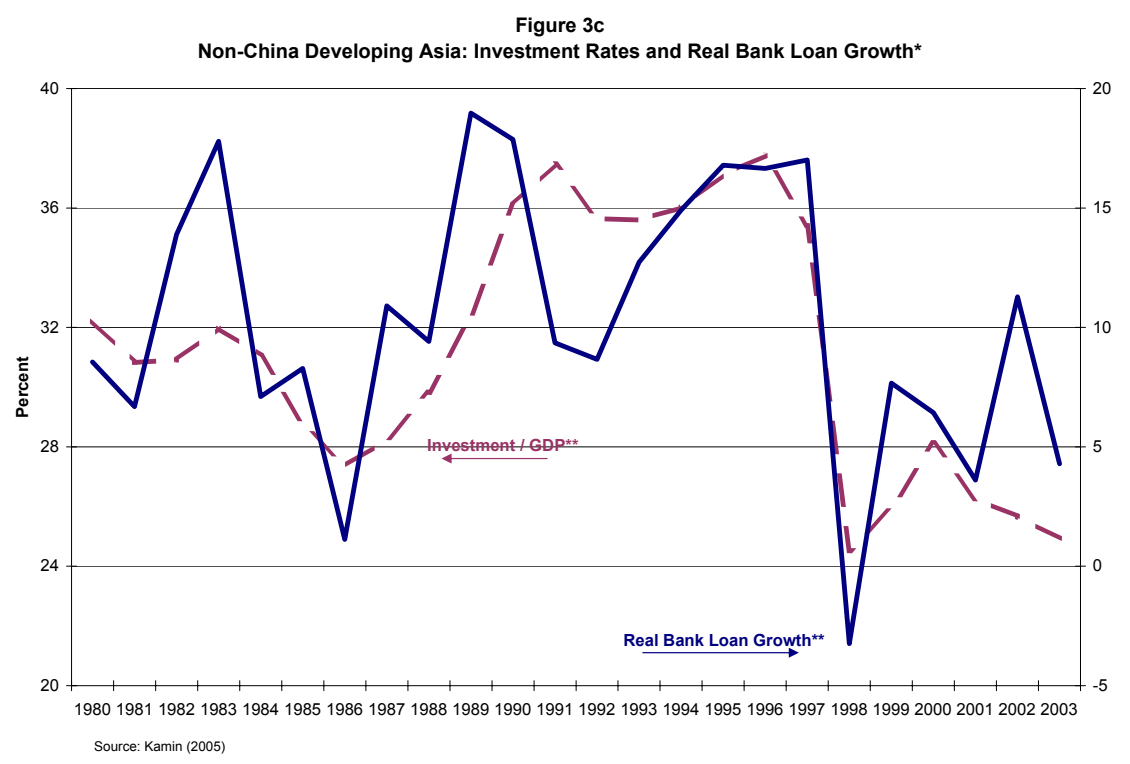

"Weighted by country shares in \$US GDP, averaged over 1980-2004.

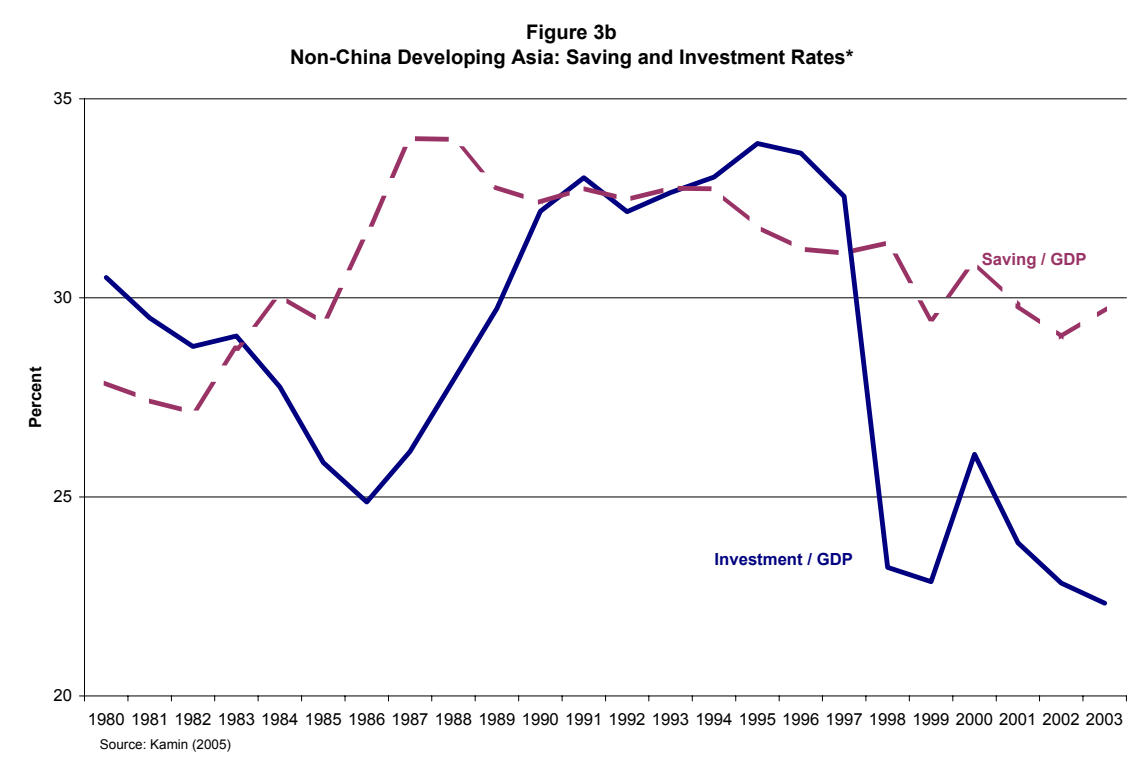

"Weighted by country shares in SUS GDP, averaged over 1980-2004.

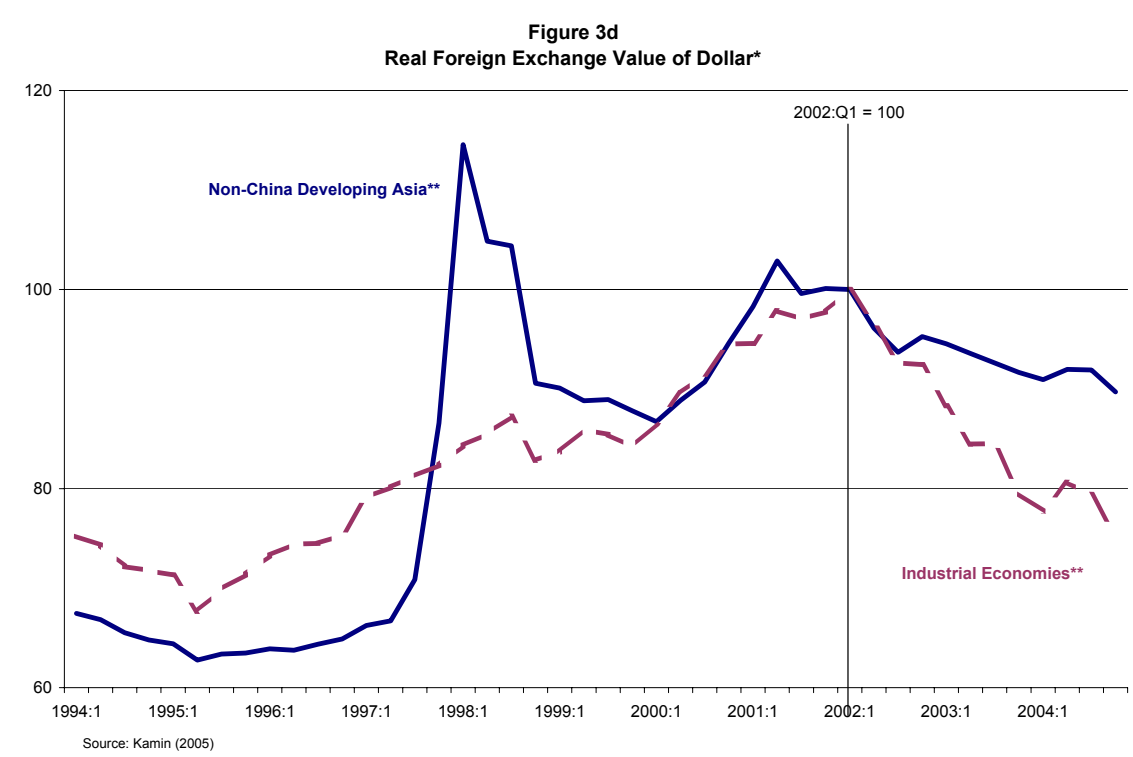

"Weighted by country shares in SUS GDP, averaged over 1980-2004.

"An increase indicates dollar appreciation. 
Figure 4: GDP-Weighted Financial Crisis Dummy

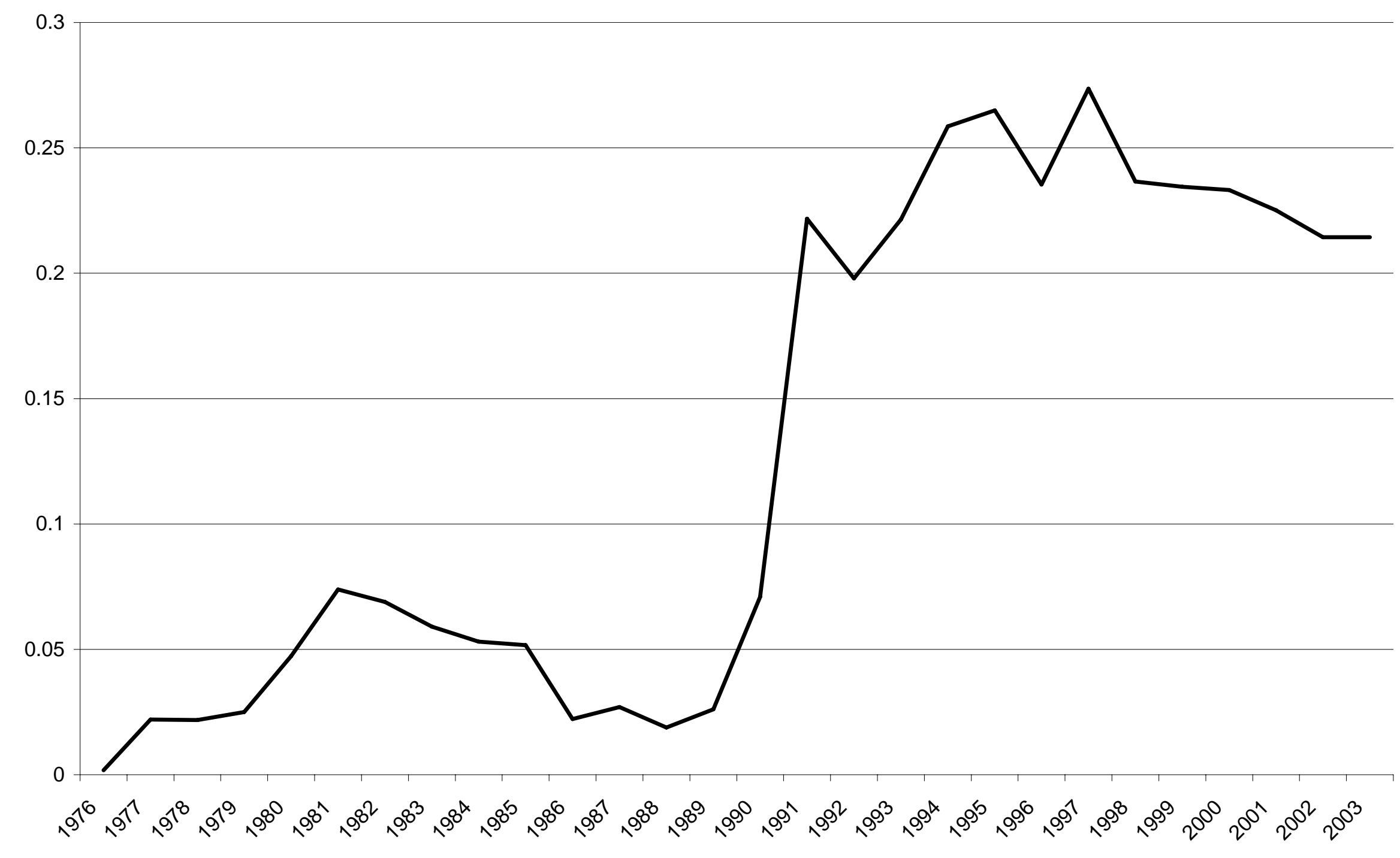


Figure 5: Table1 - Regression 1

(1997 - 2003 Period)

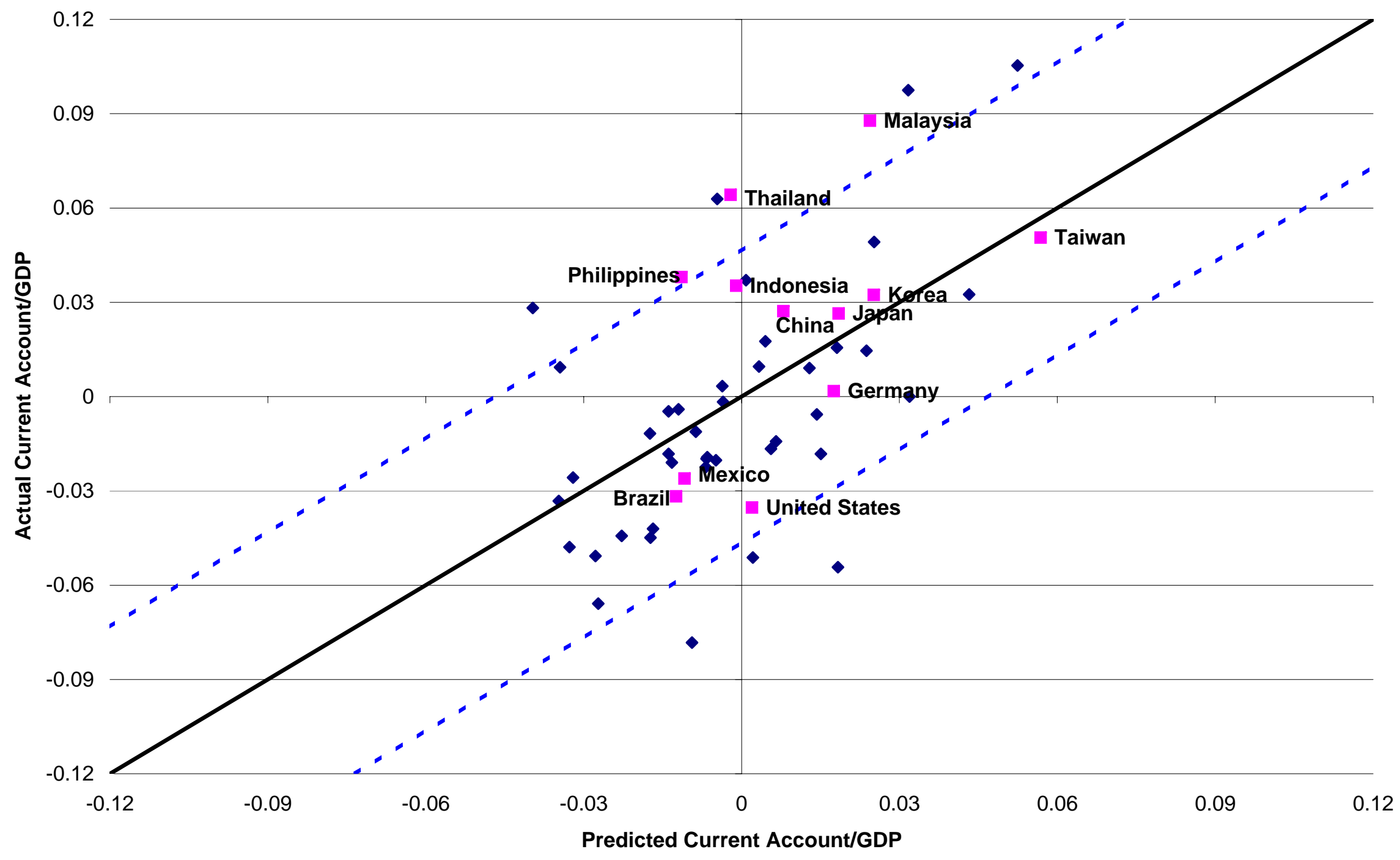


Figure 6: Table1 - Regression 3

(1997 - 2003 Period)

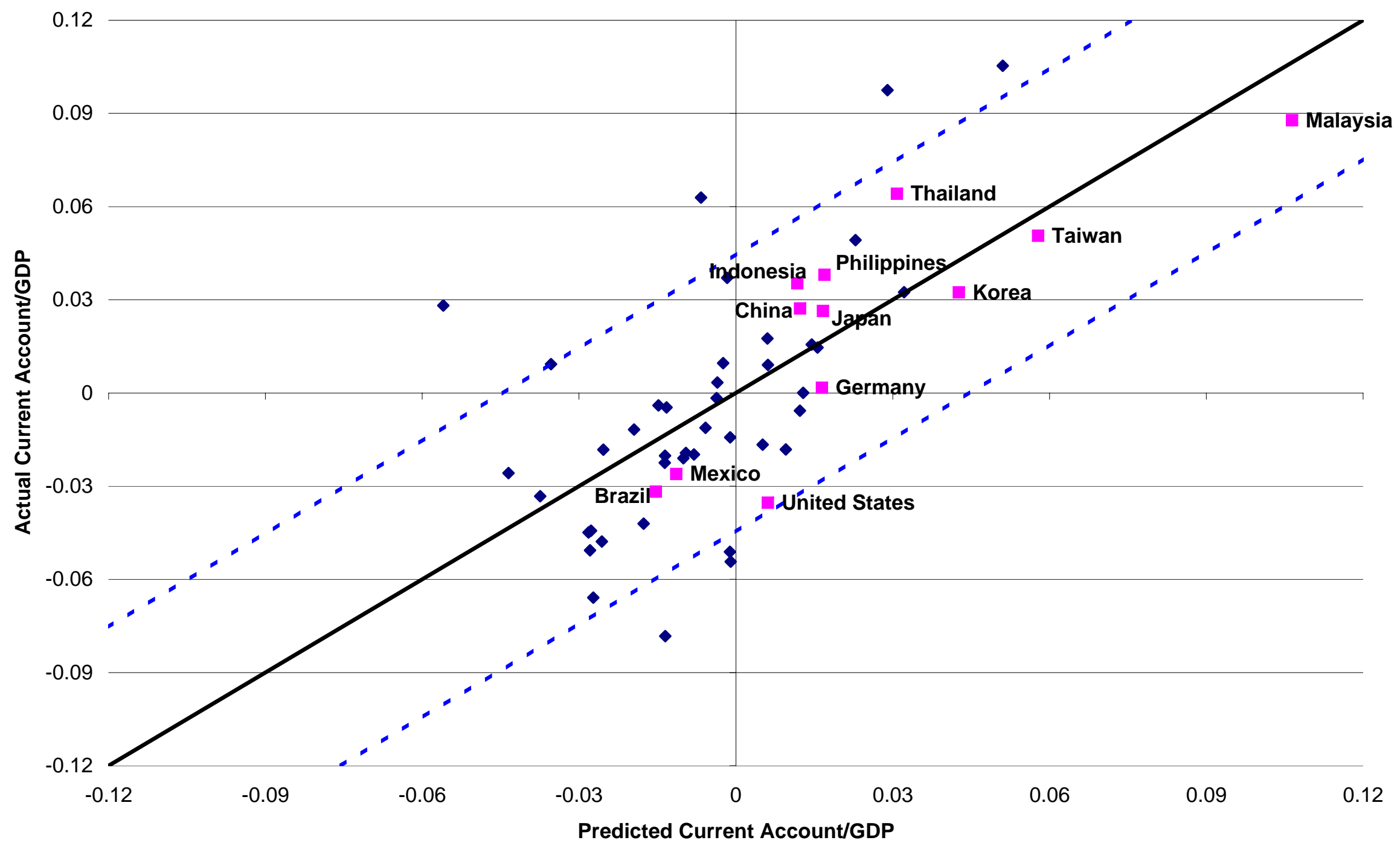

Page 32 
Figure 7: United States - Contribution to Predicted Current Account/GDP

(Table 2 - Regression 3)

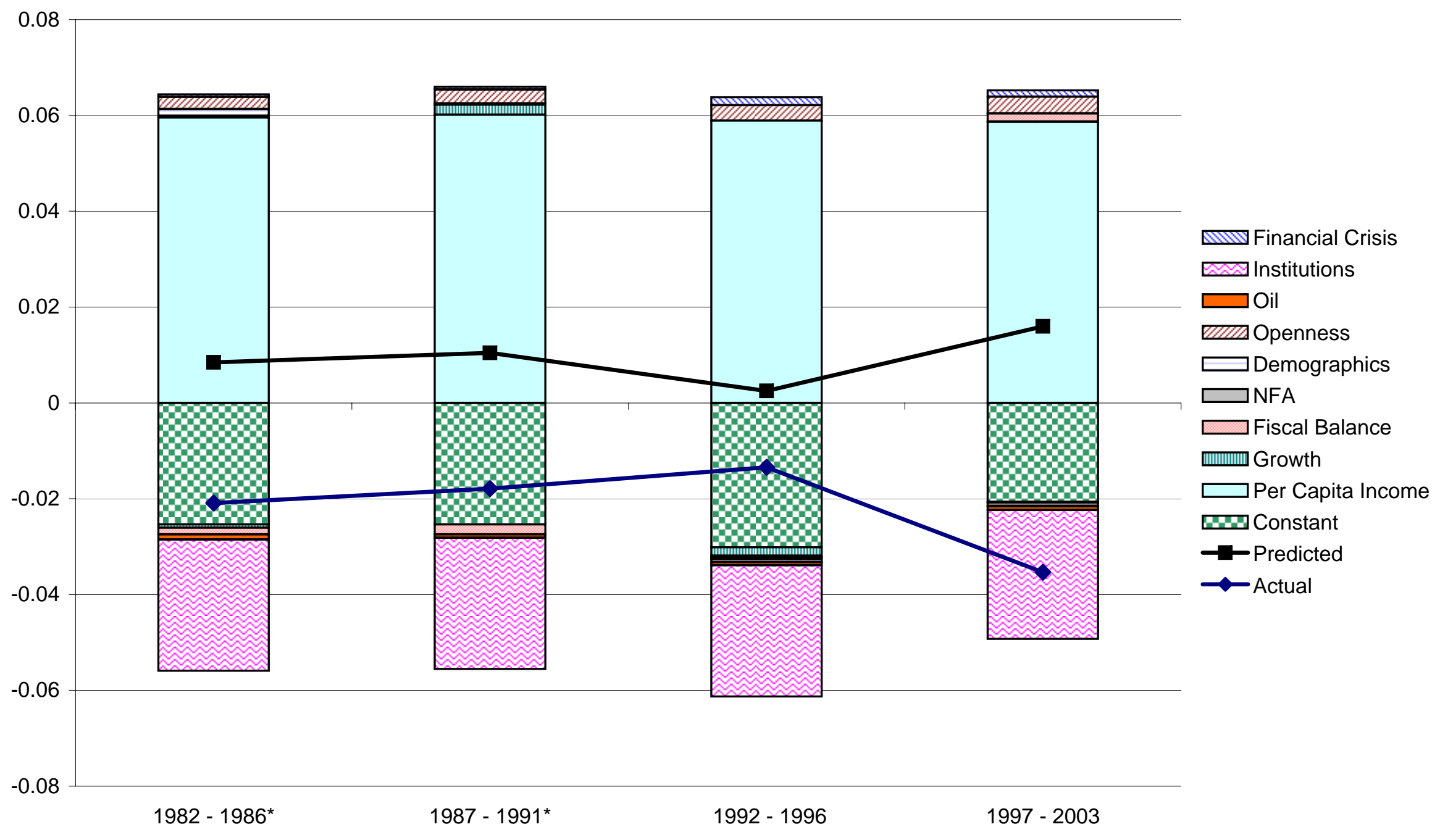

*1982 - 1986 and 1987 - 1991 backcast using Table 2 - Regression 3 coefficients, the 1992-1996 value for the institution variable, and no fixed effect. 
Figure 8: GDP-Weighted Asian Aggregate - Contributions to Predicted Current Account/GDP (Table 2 - Regression 3)

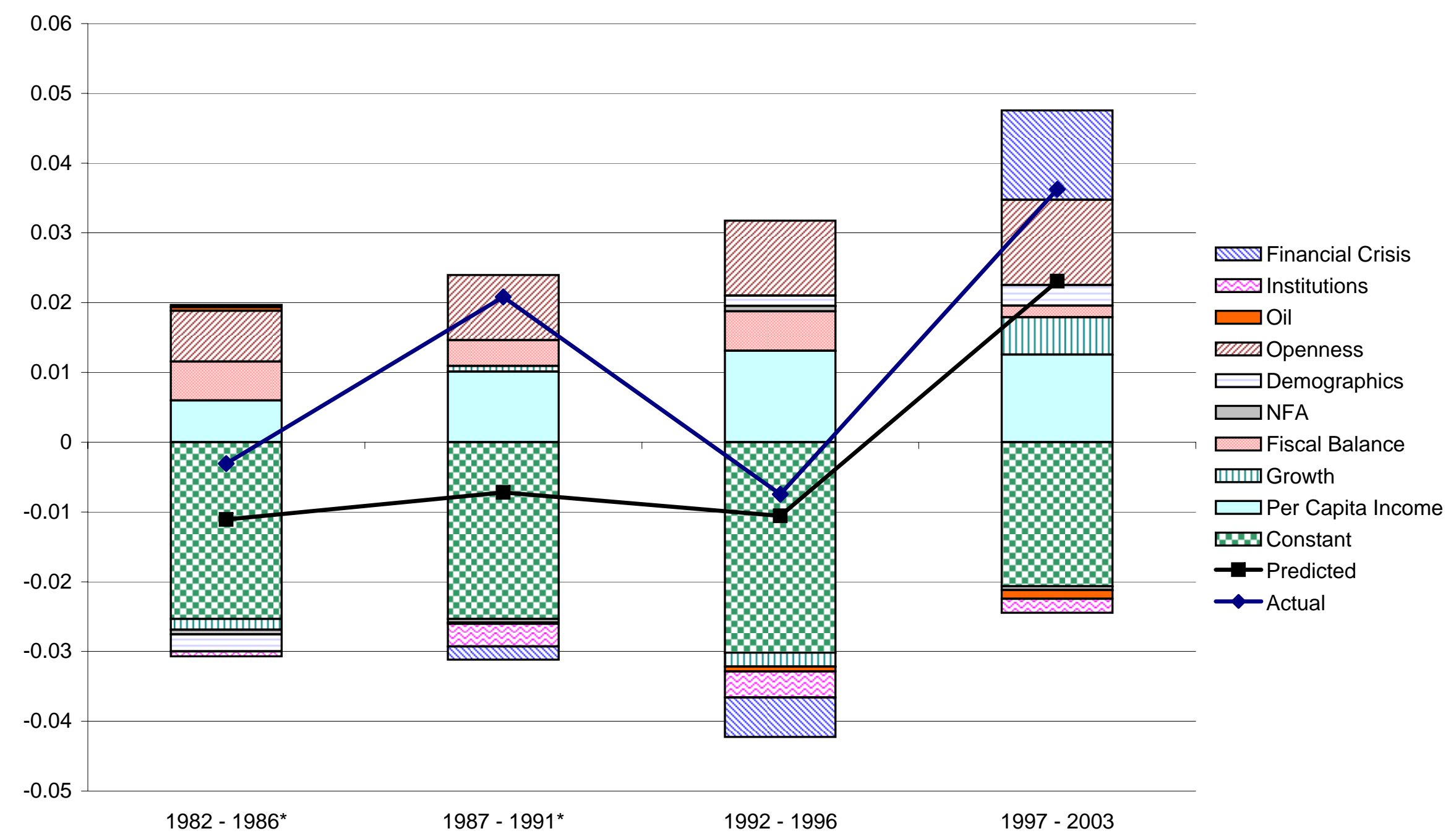

*1982 - 1986 and 1987 - 1991 backcast using Table 2 - Regression 3 coefficients, the 1992-1996 value for the institution variable, and no fixed effect. 
Figure 9: 1997 - 2003 Contributions to Predicted Current Account/GDP (Table 2 - Regression 3)

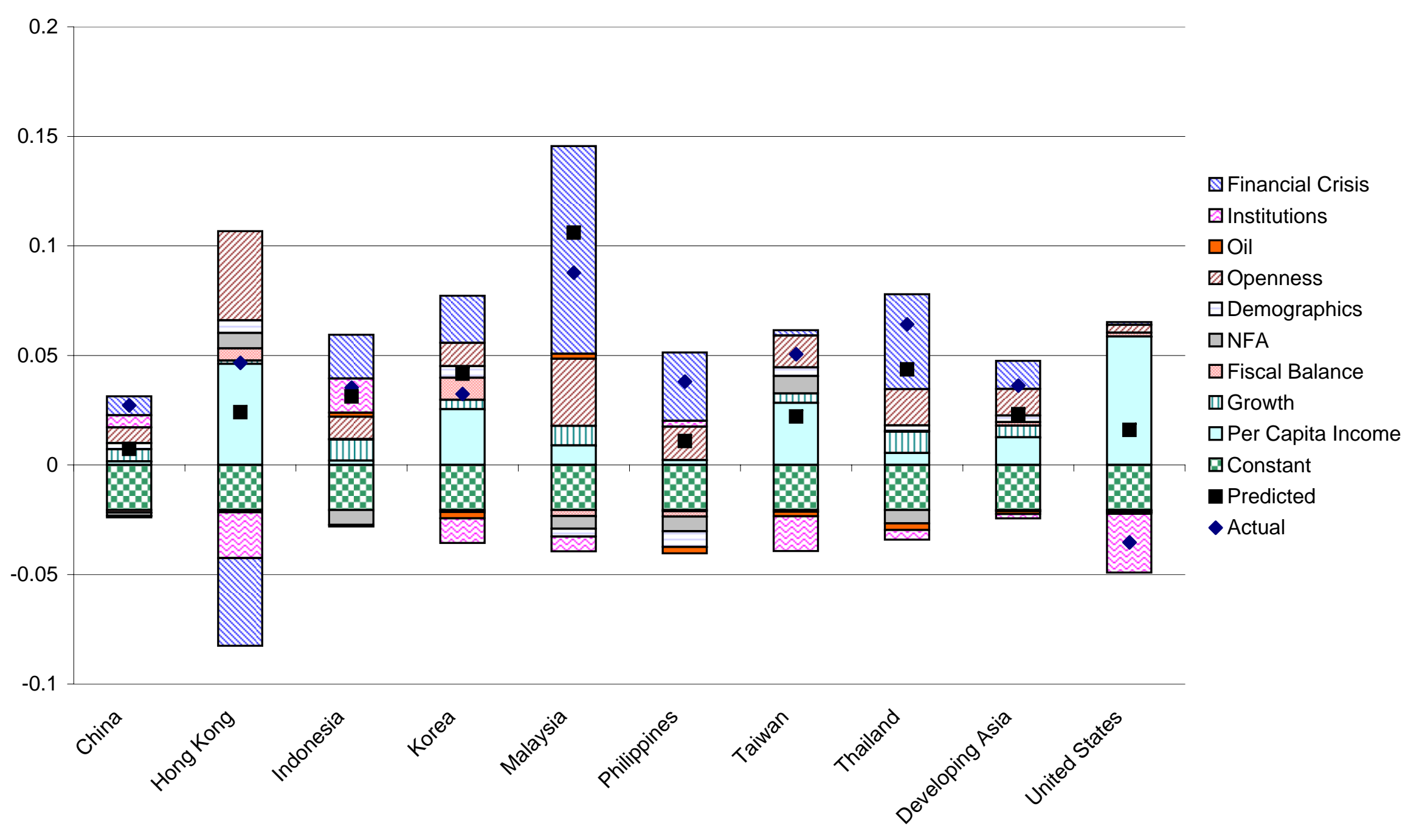


Figure 10: Current Account vs. Oil Balance

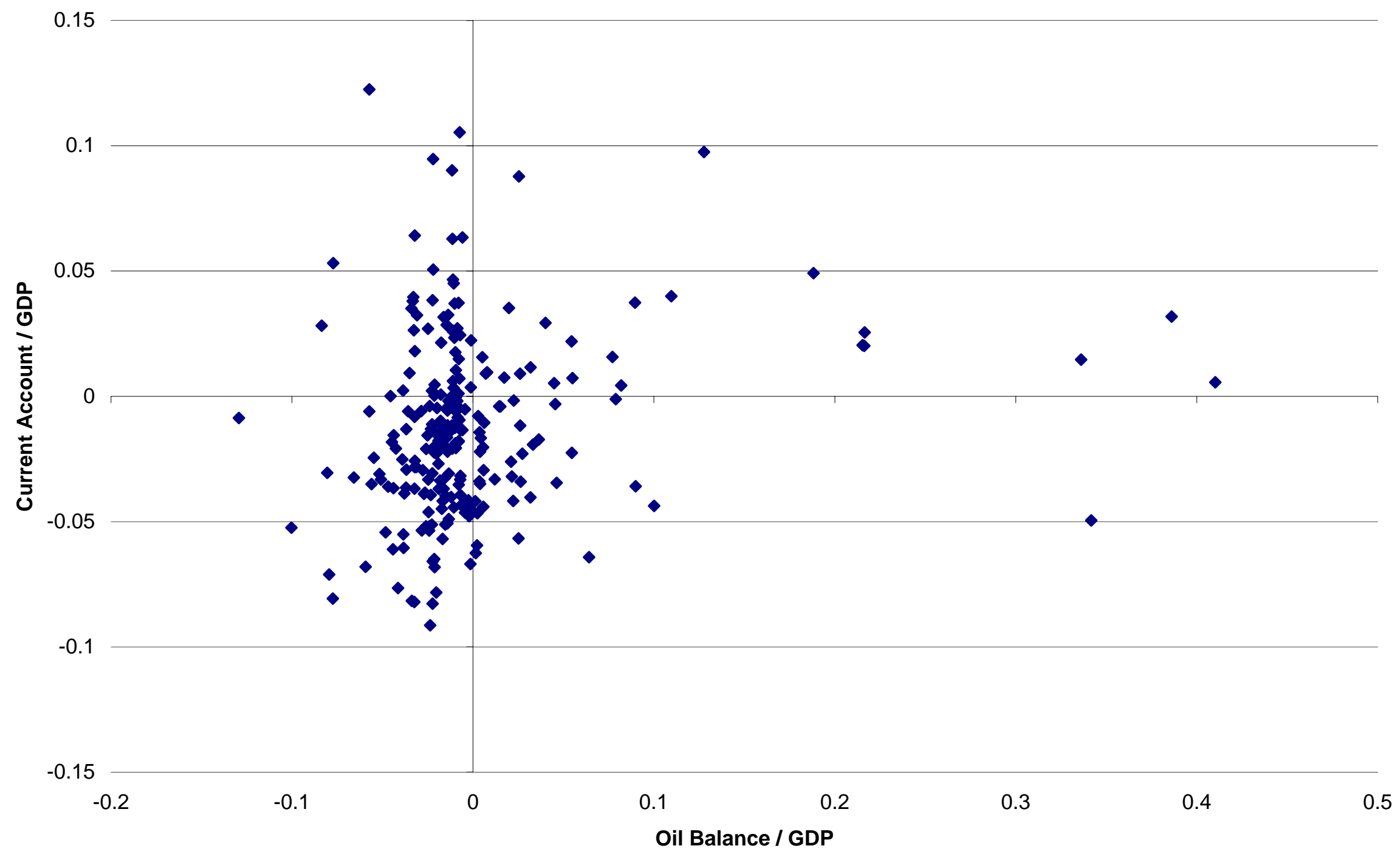

